\title{
A meta-analysis on the price elasticity of energy demand
}

Xavier Labandeira

José M. Labeaga

Xiral López-Otero 


\title{
A meta-analysis on the price elasticity of energy demand
}

\author{
Xavier Labandeira a,b, José M. Labeaga c, ${ }^{*}$, Xiral López-Otero a \\ a Rede, Universidade de Vigo, Facultade de CC.EE., Campus As Lagoas s/n, 36310 Vigo, Spain \\ b FSR Climate, European University Institute, Via delle Fontanelle 10, 50014 San Domenico di Fiesole, Italy \\ c Departamento de Análisis Económico, UNED, Senda del Rey 11, 28040 Madrid, Spain
}

\begin{abstract}
Price elasticities of energy demand have become increasingly relevant in estimating the socio-economic and environmental effects of energy policies or of other events with influence on the prices of energy goods. Since the 1970s a large number of academic papers have provided both short and long-term price elasticity estimates for different countries by using several models, data and estimation techniques. Yet the literature offers a rather wide range of estimates for the price elasticities of demand for energy. This paper quantitatively summarizes the recent, but still sizeable, empirical evidence on this matter to facilitate a sounder economic assessment of energy price changes. It does so by using meta-analysis to identify the main factors affecting the elasticity results, both short and long term, for energy in general as well as for specific products: electricity, natural gas, gasoline, diesel and heating oil.
\end{abstract}

Keywords: short-term, long-term, electricity, gas, gasoline, diesel, oil

JEL Classification: C13, C83, Q41

\footnotetext{
*Corresponding author: jlabeaga@cee.uned.es
}

The authors acknowledge funding from the Spanish Ministry of Science and Innovation projects ECO2012-39553C04-01 (Labeaga), ECO2013-41183-P (Labandeira) and Cátedra FENOSA at the University of Vigo (Labandeira and López-Otero). The usual disclaimers apply. 


\section{Introduction}

Energy is a key element in contemporary economies not only for the production of goods and services but also as a direct source of welfare for individuals. It is therefore essential to know how price changes, brought about by market dynamics and/or energy-related public policies, affect energy demand of producers and consumers. Over the last few years energy deregulation and sharp movements in the price of primary energy goods, together with policies related to climate change and energy security concerns, have actually fostered a renewed interest in this area. Energy savings are likely to play a crucial role for the attainment of climate objectives (see e.g. IPCC, 2014), hence the need to correctly quantify actual mitigation potentials within energy demands, and thus energy goods may be particularly exposed to price increases and collateral distributive effects from post-Paris climate policies. Robust evidence on price elasticities of energy demand would therefore allow for a better understanding of the economic, distributional and environmental consequences of varying energy prices and would enable societies to take exante informed decisions on energy and environmental matters.

Although the economic literature on energy demand dates back to the last century (it began with Houthakker, 1951), in recent years a large number of academic studies have used several techniques to estimate the (both short and long-term) price elasticity demand of different energy products in various countries, thus yielding quite a sizeable empirical evidence. In this context, and given the above-mentioned practical relevance of price elasticities of energy demand, developing methods that summarize (qualitatively and quantitatively) the existing evidence and that identify the main factors that systematically affect results is particularly interesting. Metaanalysis, or the statistical study of studies in an area, first proposed by Glass (1976) in the field of education but subsequently extended to many other disciplines, seems to be an appropriate and useful approach for these purposes. After the work of Stanley and Jarrell (1989) multiple metaanalyses have been conducted in economics with at least one third of the studies related to environmental and resource economics (Nelson and Kennedy, 2009).

Unfortunately the use of meta-analysis in the field of energy demand has been rather limited, with the few existing exercises focusing almost exclusively on price elasticities of gasoline demand. Therefore a first objective of this paper is to incorporate other energy goods, namely electricity, natural gas, diesel, heating oil and energy in general, so that a richer analysis and conclusions of the growing empirical evidence on price elasticities in the energy domain can be provided. The 
paper also contemplates both aggregated demand for energy as well as residential, industrial and commercial demand. Moreover, the article just deals with the latest evidence available (papers published as of 1990) for two reasons: the need to update and relate the scarce academic contributions that have previously considered these matters through comparable methodologies, and the increase in the quality and reliability of results due to the significant technical advances in data collection and processing seen over the last two decades.

This piece of research carries out a meta-analysis with the procedure suggested by Nelson and Kennedy (2009) using the methodology of regression analysis (see also Stanley and Jarrell, 1989), that is, it performs a regression analysis employing the entire set of results selected from the literature and an extensive specification of the factors that determine these elasticities. The paper thus responds to the need to determine, as precisely as possible, the value of price elasticities of demand for energy in general as well as those for the demand of the abovementioned energy goods. As a secondary outcome, the paper identifies the variables that explain the heterogeneity of the price elasticities reported by the literature.

The article is divided into five sections, including this introduction. The second section describes existing academic literature with the use of meta-analysis to summarize and analyze price elasticities of energy demand. The subsequent part provides details on the empirical application implemented in the article, also describing the factors that influence the estimation of price elasticities of energy demand. Section 4 presents the empirical results from the use of metaanalysis on the updated literature review, and Section 5 concludes the article. Additionally the paper includes two annexes with, respectively, the full estimation results and the list of papers employed in the meta-analysis.

\section{Meta-analyses of price elasticities of energy demand}

Although numerous papers have provided estimates of the price elasticity of demand for energy (see, e.g., Taylor, 1975, Dahl and Sterner, 1991, Madlener, 1996, Graham and Glaister, 2002b, or Dahl, 2012), relatively few studies in the literature have conducted a meta-analysis of these elasticities. Moreover, as shown by Table 1, the few existing meta-analysis have been mainly applied to the literature on price elasticities of gasoline demand. 
In particular, Espey (1996) carried out the first meta-analysis to examine the existence of factors that systematically affect the estimates of gasoline price (and income) elasticities in the United States, including as explanatory variables the characteristics of the data, the model structure and the estimation technique. An extension of this article is provided in Espey (1998), with the use of existing empirical evidence on gasoline demand across the globe and the separate analysis of long-term and short or medium-term elasticities. This paper employs the functional form, the structure of delays, the sampling period, the country, the estimation technique and other structural characteristics of the model as explanatory variables. Subsequently, the UK Department of Transport commissioned two reports (Hanly et al., 2002; Graham and Glaister 2002a) to identify the magnitude and ranges of road transport elasticities provided by the existing literature, and to distinguish price elasticities by type of traffic and different definitions of costs and prices. Within this context the reports also conducted a meta-analysis, akin to that of Espey (1998), on price elasticities of demand for car fuels.

Regarding price elasticities of other energy sources, Espey and Espey (2004) carried out the only meta-analysis that analyzes residential electricity demand. This paper examines how the values of the short and long-term price elasticities are affected by the specification of the demand model, the characteristics of the data used, the country for which the exercise is conducted, the period of analysis and by the estimation technique.

The latest contributions to the literature of meta-price elasticities of energy demand are those of Brons et al. (2008) and Havranek et al. (2012). In the first case the authors performed a metaanalysis to enquire on the variation in empirical estimates of the price elasticity of demand for gasoline, developing an estimation method based on the Seemingly Unrelated Regression (SUR) model and assuming that gasoline demand may be expressed as a multiplicative function of car fuel efficiency, mileage per vehicle and vehicle ownership, which implied a linear relationship between the price elasticity of the total demand for gasoline and the price elasticities of each of these variables. The combination of information on different types of elasticities allowed Brons et al. (2008) to obtain more precise estimates. Havranek et al. (2012), on the other hand, approached this issue through a meta-analysis of the estimates of gasoline demand elasticities across different countries. This study considered that the distribution of the estimated elasticities might be explained by the type of data used, the date of publication of the study and an indicator of whether the data are for the US. The paper employed, for the first time in the field, the socalled Heckman meta-regression (see Stanley and Doucouliagos, 2007) to correct selection bias 
in the existing publications that report these elasticities. Biases in average price elasticities occur because positive or non-significant estimates of price elasticities are rarely reported while overly negative elasticities are regularly published.

Table 1. Meta-analyses for price elasticity of demand for energy in literature

\begin{tabular}{|c|c|c|c|c|c|}
\hline Study & Period & $\begin{array}{c}\text { Considered } \\
\text { papers }\end{array}$ & Observations & $\begin{array}{l}\text { Energy } \\
\text { Product }\end{array}$ & Elasticities \\
\hline Espey (1996) & $1936-1990$ & 41 & 70 & Gasoline & $-0.65(\mathrm{LT})$ \\
\hline Espey (1998) & 1929-1993 & 101 & 640 & Gasoline & $\begin{array}{l}-0.16(\mathrm{LT}) \\
-0.81(\mathrm{LT})\end{array}$ \\
\hline Hanly et al. (2002) & 1929-1991 & 69 & 491 & Car fuels & $\begin{array}{c}-0.76 \text { (ST) } \\
-1.16 \text { (LT) } \\
-0.54 \text { (STA) }\end{array}$ \\
\hline Graham and Glaister (2002a) & $1966-2000$ & 113 & 600 & Car fuels & $\begin{array}{l}-0.25 \text { (ST) } \\
-0.77(\mathrm{LT}) \\
\end{array}$ \\
\hline Espey and Espey (2004) & $1947-1997$ & 36 & 248 & Electricity & $\begin{array}{l}-0.35(\mathrm{ST}) \\
-0.85(\mathrm{LT}) \\
\end{array}$ \\
\hline Brons et al. (2008) & $1949-2003$ & 43 & 312 & Gasoline & $\begin{array}{l}-0.36(\mathrm{ST}) \\
-0.81(\mathrm{LT}) \\
\end{array}$ \\
\hline Havranek et al. (2012) & $1974-2011$ & 41 & 202 & Gasoline & $\begin{array}{l}-0.09 \text { (ST) } \\
-0.31(\mathrm{LT}) \\
\end{array}$ \\
\hline
\end{tabular}

Source: Brons et al. (2008) and the cited literature

Note: LT, long term; ST, short term; STA, result obtained by using only papers that employ statistical models

The results of these studies show a price elasticity of energy products in the short term ranging between -0.09 and -0.76 , while they report long-term elasticities between -0.31 and -1.16 . The preceding papers also show that, in absolute value, elasticities have a tendency to decrease over time. This phenomenon could reflect income effects as well as the influence of energy-efficiency improvements that would lead consumers to be less sensitive to price changes.

\section{Meta-analysis}

As suggested by Nelson and Kennedy (2009), in this paper we perform a meta-regression analysis (Stanley and Jarrell, 1989), that is, we carry out a regression analysis of the whole set of coefficients included in the papers selected for this piece of research (see Annex II). Therefore, this article intends to adjust the value of price elasticities of demand for energy as precisely as possible, identifying the factors that explain the differences between the results of the various studies. It does so by estimating the model

$$
b_{j}=\beta+\sum_{k=1}^{K} \alpha_{k} Z_{j k}+e_{j} \quad(j=1,2, \ldots, L)
$$


where $b_{j}$ is the estimation carried out in the $j$-nth study using the real value of the price elasticity of demand for energy $(\beta), Z$ are the explanatory variables that measure the relevant characteristics of the empirical study that influence estimated elasticities, $\alpha_{k}$ are the coefficients of the meta-regressions that reflect the bias introduced by the particular characteristics of the study, $e_{j}$ is the error term of the meta-regression, and $L$ is the number of studies employed in the analysis. As in previous meta-analyses in this area, different models are estimated for short and long-term elasticities of energy demand.

The papers, whose results were used to conduct the meta-analysis, were selected from a fully updated, comprehensive and detailed review of the existing empirical literature on price elasticities of energy demand. Most papers were actually found by consulting previous surveys and meta-analyses on this matter, although extensive internet search tools (including Google Scholar and ScienceDirect) were also employed. Among the sources to identify and compile the studies used in this article special mention deserves the Dahl Energy Demand Database (Dahl, 2010). In total 416 papers produced between 1990 and 2014 were collected, providing 951 short term price elasticities and 991 long-term price elasticities of energy demand (see Table 1 in the preceding section for a comparison with previous meta-analyses in the field). Table 2 shows a statistical summary of the elasticities that served as the basis for the meta-analysis: estimates of the long-term elasticity range between -22 and 4.189 , with an average of -0.598 , while short-term elasticity estimates range from -24 to 2.908 , with an average of -0.237 . The upper panel of Figure 1 shows the density of the total sample of estimated short and long-term elasticities.

As some of the estimated values of elasticities are very extreme and statistically non-significant, usually due to small sample sizes, we decided to exclude $5 \%$ of the sample from the metaanalysis $(2.5 \%$ of values in the upper tail and $2.5 \%$ of the values in the lower tail of the distribution) in order to eliminate outliers that may strongly affect the results of the estimation of Equation 1. Table 2 summarizes, under the heading selected sample, the statistics that describe the elasticities used in the analysis, with short-term price elasticities ranging between -0.803 and 0.067 and long-term elasticities in an interval between -1.809 and 0.154 , while the lower panel of Figure 1 shows the density of the elasticities actually considered in this paper. 
Table 2. Statistics of price elasticities of demand. Total and selected samples

\begin{tabular}{|c|c|c|c|c|c|c|}
\hline Variable & Observations & Average & Median & $\begin{array}{c}\text { Standard } \\
\text { Deviation }\end{array}$ & Minimum & Maximum \\
\hline \multicolumn{7}{|c|}{ Total sample } \\
\hline ST Elasticity & 951 & -0.237 & -0.139 & 0.887 & -24.0 & 2.908 \\
\hline LT Elasticity & 991 & -0.598 & -0.427 & 1.130 & -22.0 & 4.189 \\
\hline \multicolumn{7}{|c|}{ Selected sample } \\
\hline ST Elasticity & 903 & -0.186 & -0.139 & 0.169 & -0.803 & 0.067 \\
\hline LT Elasticity & 941 & -0.524 & -0.427 & 1.392 & -1.809 & 0.154 \\
\hline
\end{tabular}

Note: ST, short term; LT, long term

Figure 1. Density of the elasticities. Total and selected samples

Total Sample

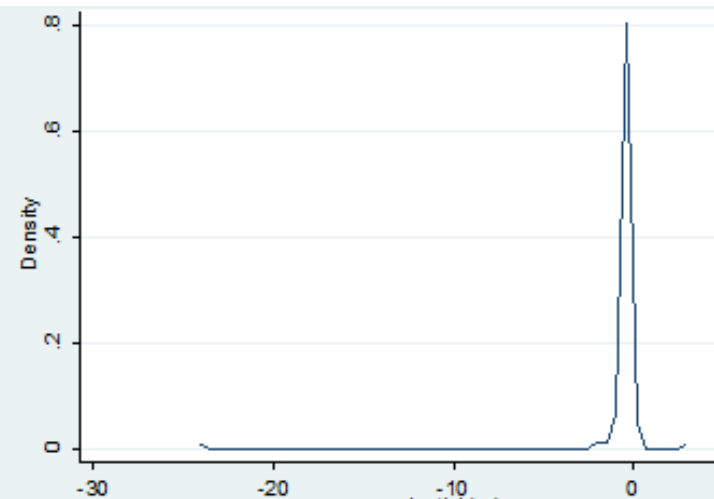

Short-term elasticities

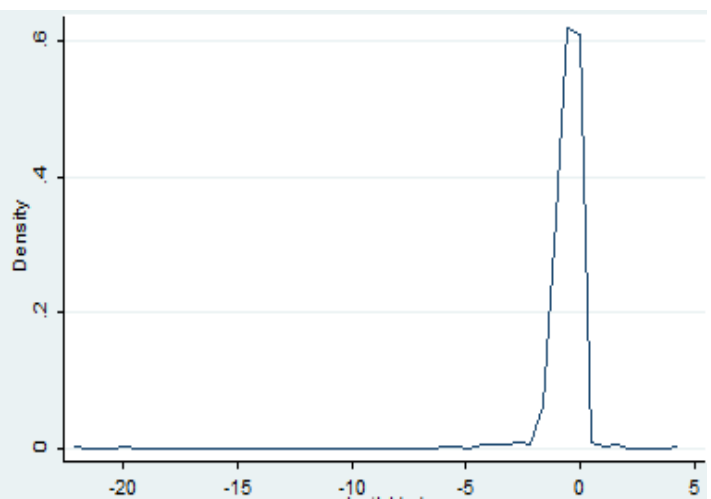

Long-term elasticities

Selected sample

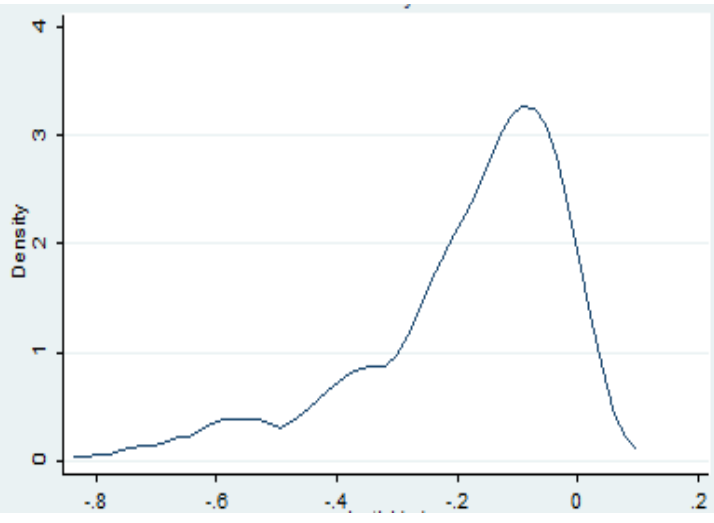

Short-term elasticities

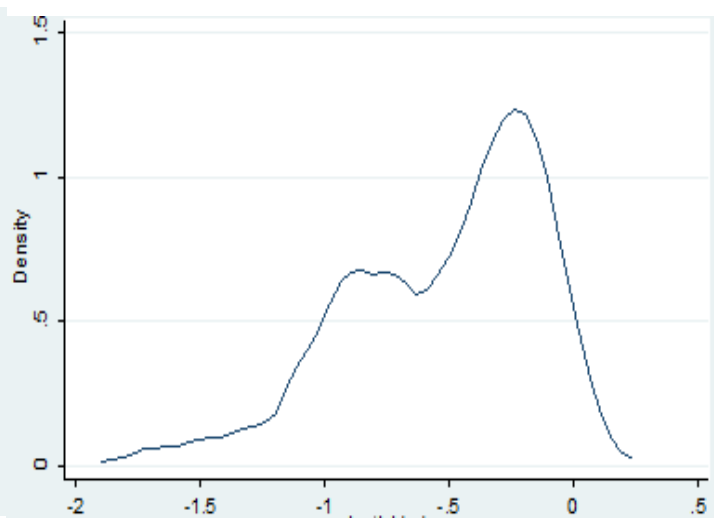

Long- term elasticities

Given the heterogeneity of the selected empirical studies, which brings about an important variation in the estimated elasticities, a number of indicators (constructed as variables $0-1$ ) were introduced to capture the various sources of heterogeneity. We considered eight main factors or determinants that could affect the estimation of elasticities, as listed below and summarized in Table 3: 
- Type of energy product. Since the reaction of consumers to price changes may be different in function of the energy product consumed, the exercise distinguishes between the studies estimating the price elasticity of demand for energy in general and those estimating the price elasticities of demand for each of the main energy products, i.e., electricity, natural gas, gasoline, diesel and heating oil.

- Type of consumer: Energy is used for different purposes in function of the general type of consumer demanding it, which itself influences the effect of prices on demand. The exercise therefore distinguishes between studies estimating residential, industrial, commercial, and total energy consumption.

- Country (geographical area). The behavior of energy consumers can be very different in function of the country under analysis. So in this case the exercise considers two factors that may affect estimated elasticities: stage of economic development (developed and developing countries), and energy trade balance (net energy exporters and importers). For these purposes, the paper uses the Human Development Index (UNDP, 2015) to identify developed countries as those with HDI above the median, and World Bank data (World Bank, 2015) concerning net energy imports/exports of countries. ${ }^{1}$

- Data. Another important factor that can influence the results is the type of data used in each particular study. The exercise therefore distinguishes between studies using crosssectional data, those employing time series data and papers that use panel data.

- Type of model. On the one hand, a large part of the existing empirical research on energy demand has employed dynamic (usually error-correction) models estimated with cointegration techniques on aggregate data (Engle and Granger, 1987). However, the validity of the results obtained with these approaches largely rests on the existence of representative consumers, disregarding the information related to the behavior of individual agents and thus being unable to deal with observable and unobservable heterogeneity. An available alternative when information for individual agents (consumers, companies, etc.) exists is to adjust models that explicitly consider these factors. When using micro data, a first option consists in estimating energy demand using standard econometric techniques although, even under these circumstances, it is unlikely that all the decisions of the agents concerning energy demand will be taken into account. For example, the relationship between the discrete decision to purchase durable goods that consume energy and the decision to consume energy is rarely considered. This may lead to inadequate specifications in models, causing a biased estimation of elasticities and thus invalidating the inference relative to public policies and/or price shocks. Within this context, an alternative may be to

\footnotetext{
1 When a given estimation uses data from several countries, these dummies reflect the type of country that represents a majority within the group.
} 
use continuous-discrete sequential models that assume agents who first take discrete decisions on the purchase of durable energy-consuming goods and, conditioned by them, subsequently decide on how much energy to consume.

On the other hand, most empirical studies in this area have used single-equation econometric models that require separability restrictions. This is a severe disadvantage as it is not possible to estimate cross-price effects between different energy products or consider the effects of non-energy products on the price elasticity of energy goods. An alternative is to estimate price elasticities using complete systems of demand, such as the translog model (Christensen et al., 1973) or the almost ideal demand system (Deaton and Muellbauer, 1980), AIDS, which allow the correction of various econometric problems that usually cause biases in the estimation of elasticities.

- Sample period. It is widely accepted that the economic cycle has a strong influence on energy consumption due to income and (indirect cycle-related) price effects. In the case of economic crises, for example, a depression of energy prices may occur and reduced disposable income may lead agents to reduce consumption through improvements in energy efficiency, adjustments to other types of consumption or changes towards other more inexpensive energy goods. Thus the exercise incorporates a series of dummies indicating whether most of the sample period of each considered study is before or after the crises of 1973, 1979 and 2008.

- Type of publication. The exercise introduces a dummy to distinguish between papers published in peer-review journals from studies published in alternative formats such as working papers series, reports, etc.

- Estimation method. The exercise also considers that the procedure used to estimate the model may affect the results. Thus there is a distinction between papers using least squares methods, from single equations estimated by ordinary least squares (OLS) to iterate least squares (ILS), papers with multiple equations, as seemingly unrelated regression equations (SURE), panel data models estimated by least squares dummy variables (LSDV) and generalized least squares (GLS). Papers with single equation or multiple equation models estimated by instrumental variables as two-stage or three-stage least squares (2SLS or $3 S L S)$ or generalized method of moments (GMM) are also contemplated. Finally, the exercise also incorporates papers that use alternative estimation approaches such as maximum likelihood methods, Bayesian methods, ridge regression or nonparametric estimation. $^{2}$

\footnotetext{
${ }^{2}$ A description of most of the above-mentioned estimation methods can be found in Wooldridge (2002). For nonparametric methods and Bayesian procedures seminal references are respectively Härdle and Linton (1994) and Chib et al. (2008).
} 
Table 3. Main determinants affecting elasticity demand estimation

\begin{tabular}{|c|c|c|c|}
\hline \multirow{2}{*}{ Determinants } & \multirow{2}{*}{$\begin{array}{c}\text { Number of } \\
\text { observations }\end{array}$} & \multicolumn{2}{|c|}{ Average elasticity } \\
\hline & & Short-term & Long-term \\
\hline $\begin{array}{l}\text { Good } \\
\text { Energy } \\
\text { Electricity } \\
\text { Natural gas } \\
\text { Car fuels } \\
\text { Gasoline } \\
\text { Diesel } \\
\text { Heating oil }\end{array}$ & $\begin{array}{c}372 \\
516 \\
229 \\
82 \\
465 \\
136 \\
44\end{array}$ & $\begin{array}{l}-0.149 \\
-0.203 \\
-0.184 \\
-0.180 \\
-0.194 \\
-0.157 \\
-0.188\end{array}$ & $\begin{array}{l}-0.570 \\
-0.520 \\
-0.566 \\
-0.358 \\
-0.526 \\
-0.391 \\
-0.534\end{array}$ \\
\hline $\begin{array}{l}\text { Consumer } \\
\text { Residential } \\
\text { Industrial } \\
\text { Commercial } \\
\text { Total }\end{array}$ & $\begin{array}{c}693 \\
259 \\
59 \\
833 \\
\end{array}$ & $\begin{array}{l}-0.216 \\
-0.166 \\
-0.230 \\
-0.162\end{array}$ & $\begin{array}{l}-0.620 \\
-0.508 \\
-0.721 \\
-0.435 \\
\end{array}$ \\
\hline $\begin{array}{l}\text { Country } \\
\text { Net energy exporter } \\
\text { Net energy importer }\end{array}$ & $\begin{array}{l}481 \\
1363\end{array}$ & $\begin{array}{l}-0.189 \\
-0.185\end{array}$ & $\begin{array}{l}-0.514 \\
-0.527\end{array}$ \\
\hline $\begin{array}{l}\text { Developed } \\
\text { Developing }\end{array}$ & $\begin{array}{c}1432 \\
412 \\
\end{array}$ & $\begin{array}{l}-0.186 \\
-0.184 \\
\end{array}$ & $\begin{array}{l}-0.515 \\
-0.550 \\
\end{array}$ \\
\hline $\begin{array}{l}\text { Data } \\
\text { Cross-section } \\
\text { Time series } \\
\text { Panel data }\end{array}$ & $\begin{array}{c}182 \\
1174 \\
488\end{array}$ & $\begin{array}{l}-0.337 \\
-0.167 \\
-0.204\end{array}$ & $\begin{array}{l}-0.861 \\
-0.446 \\
-0.514\end{array}$ \\
\hline $\begin{array}{l}\text { Model } \\
\text { Aggregate data } \\
\text { Aggregate data and cointegrated (or ECM) } \\
\text { Demand system } \\
\text { Microeconomic model } \\
\text { Continuous-discrete micro model }\end{array}$ & $\begin{array}{c}1139 \\
364 \\
213 \\
83 \\
45\end{array}$ & $\begin{array}{l}-0.158 \\
-0.181 \\
-0.270 \\
-0.358 \\
-0.293\end{array}$ & $\begin{array}{l}-0.456 \\
-0.452 \\
-0.790 \\
-0.679 \\
-0.880\end{array}$ \\
\hline $\begin{array}{l}\text { Sample period } \\
\text { Pre-1973 } \\
\text { Post-1973 }\end{array}$ & $\begin{array}{c}101 \\
1743\end{array}$ & $\begin{array}{l}-0.224 \\
-0.183\end{array}$ & $\begin{array}{l}-0.634 \\
-0.518\end{array}$ \\
\hline $\begin{array}{l}\text { Pre-1979 } \\
\text { Post-1979 }\end{array}$ & $\begin{array}{c}354 \\
1490\end{array}$ & $\begin{array}{l}-0.191 \\
-0.184\end{array}$ & $\begin{array}{l}-0.551 \\
-0.518\end{array}$ \\
\hline $\begin{array}{l}\text { Pre-2008 } \\
\text { Post-2008 }\end{array}$ & $\begin{array}{c}1817 \\
27\end{array}$ & $\begin{array}{l}-0.186 \\
-0.175\end{array}$ & $\begin{array}{l}-0.526 \\
-0.323\end{array}$ \\
\hline $\begin{array}{l}\text { Publication } \\
\text { Peer-review journal } \\
\text { Other }\end{array}$ & $\begin{array}{c}1461 \\
383\end{array}$ & $\begin{array}{l}-0.193 \\
-0.151\end{array}$ & $\begin{array}{l}-0.567 \\
-0.382\end{array}$ \\
\hline $\begin{array}{l}\text { Estimation method } \\
\text { Least squares } \\
\text { Instrumental variables } \\
\text { Other methods }\end{array}$ & $\begin{array}{l}1151 \\
265 \\
428\end{array}$ & $\begin{array}{l}-0.188 \\
-0.184 \\
-0.180\end{array}$ & $\begin{array}{l}-0.458 \\
-0.559 \\
-0.641\end{array}$ \\
\hline
\end{tabular}




\section{Results and discussion}

\subsection{Results}

The model of Section 3 was estimated using GLS for both short and long-term elasticities because the elasticity figures provided by the literature, conforming a sample with two dimensions (time and type of study), could lead to heteroskedasticity and correlation of error terms given the different sample sizes of the various studies. Moreover, we attempted to control for unobserved study-specific factors with the estimation of Equation 1 by using a panel data structure in which the dimensions are the energy product under consideration and the study. It was also considered that the dimension of the sample allowed the use of random effects under the assumption of noncorrelated effects. Table 4 presents the average elasticities adjusted using the above-mentioned methods, with the top (bottom) panel reporting the short-term (long-term) elasticities. ${ }^{3}$

Table 4. Average elasticities in the empirical literature

\begin{tabular}{|l|c|c|}
\cline { 2 - 3 } \multicolumn{1}{c|}{} & \multicolumn{1}{c|}{ GLS } & Random-effects panel \\
\hline Energy & $-0.220^{* * *}$ & $-0.224^{* * *}$ \\
Electricity & $-0.231^{* * *}$ & $-0.209^{* * *}$ \\
Natural Gas & $-0.239^{* * *}$ & $-0.216^{* * *}$ \\
Gasoline & $-0.249^{* * *}$ & $-0.227^{* * *}$ \\
Diesel & $-0.213^{* * *}$ & $-0.204^{* * *}$ \\
Heating Oil & $-0.242^{* * *}$ & $-0.259^{* * *}$ \\
\hline & Long-term \\
\hline Energy & $-0.600^{* * *}$ & $-0.652^{* * *}$ \\
Electricity & $-0.677^{* * *}$ & $-0.686^{* * *}$ \\
Natural Gas & $-0.614^{* * *}$ & $-0.850^{* * *}$ \\
Gasoline & $-0.720^{* * *}$ & $-0.715^{\star * *}$ \\
Diesel & $-0.620^{* * *}$ & $-0.595^{* * *}$ \\
Heating Oil & $-0.747^{* * *}$ & $-0.764^{* * *}$ \\
\hline
\end{tabular}

Note: ${ }^{* *}$ Significant at the $1 \%$ level.

Regarding the results obtained for the specification estimated using random effects panel data models, which will be later compared to alternative methodological outcomes, the short-term price elasticity of energy demand is, on average, -0.22 , with diesel being the least elastic good and heating oil being the most elastic one (which reflects not only the evolution of its own price but also the substitution possibilities among energy sources for heating). In all cases, the dispersion

\footnotetext{
3 Table A1 and Table A2 in Annex I show the complete results of the estimates. Note that the alternatives presented in this section were not the only ones used: they were actually selected by rigorously contrasting their robustness, as further discussed in the paper.
} 
of price elasticities is quite small: estimates from GLS are slightly higher in absolute value, with the exception of the results for energy in general and heating oil. However, these observed differences are not statistically significant.

A second relevant matter refers to the factors affecting the reported elasticities. Regarding shortterm price elasticities the use of micro data generates significantly higher elasticities (in absolute value) than do aggregate models. This is, intuitively, an unexpected outcome since microeconomic models include a wide range of socioeconomic and demographic variables that could induce a reduction on price effects. Therefore, it is necessary to turn to other factors to obtain a coherent explanation for these results. Indeed, the absence of a representative consumer (and, thus, unobserved heterogeneity as well as correlated heterogeneity) could affect the estimates of price effects in much the same way. The reported results also show that residential and commercial demands have a remarkably higher short-term sensitivity to prices than do the industrial or aggregate demands. In aggregate models that adjust industrial energy demand, the most important factor explaining this phenomenon is the business cycle (GDP change): actually, conditional on the business cycle, prices have a limited impact on demand.

With regard to long-term elasticities, the average value is -0.65 : higher and with a greater dispersion than the reported short-term results. Significant differences among different goods, with diesel being the most inelastic product and natural gas being the most elastic one, are also found. As expected, GLS estimation results are similar to those obtained using panel data techniques. Long-term results are explained by a number of factors: the first oil crisis, type of energy consumed and type of data employed and modeling strategy of the studies (see Table A2). The meta-analysis indicates that long-term price elasticities are lower after the first oil shock (1973), probably due to the significant investments and behavioral changes brought about by the sharp increase in the price of energy goods. Moreover, price elasticities of commercial demand are significantly higher than those of residential and industrial demands. Price elasticities of energy demand from panel data are significantly smaller (in absolute terms, as in the previous comparisons) than those from cross-sections, although higher to the ones from time series. Finally, the use of complete demand systems leads to higher price elasticities than do single equations. This may indicate that only some of the models may be able to capture decisions at both the extensive and intensive margins, and also that complementary or substitution relationships may exist. 
With respect to the existing meta-analyses in the energy domain (see Section 2), this paper reports lower price elasticities for electricity demand ( -0.21 vs -0.35 in the short term, and -0.67 vs -0.85 in the long term). This may be related to the income effect and to the improvements in energy efficiency, as the data from the only meta-analysis on electricity (Espey and Espey, 2004) covers a much older period (1947-1997 vs 1990-2014). Similar reasons may explain the divergence between the results of this paper regarding price elasticities of car-fuels demand $(-0.20$ and -0.23 for respectively diesel and gasoline in the short term, and -0.60 and -0.72 in the long term) and the intervals of the other two meta-analyses $(-0.25,-0.76$ in the short term; -0.77 , -1.16 in the long term). Yet, our results are comparable to those reported by the four metaanalyses specifically focusing on the price elasticity of gasoline demand.

Finally, this meta-analysis does not indicate differences in the price elasticities of energy demand between developing and developed countries. However, an additional estimation that includes a dummy of OECD country indicates that price elasticities of energy demand are significantly higher in developing countries. In this sense, it is possible to infer that income convergence may have important consequences on energy demand (and indirectly on environmental matters and dependence on foreign energy stocks). Therefore, economic development may restrict the capacity of countries to reduce energy consumption through higher policy-induced energy prices.

\subsection{Discussion and testing}

A major potential determinant of energy demand is technical progress. Given that the importance of technical progress depends on the time period under observation, an average for each of the periods was calculated in order to assign the value of the trend. The first year of data is 1945 , so this new variable takes value 1 in that year and subsequently the value to the trend is assigned following the average of the calculated sample period. Note that the trend is not significant at any level in any given specification.

Another specification issue that may affect the estimates is the departure from normality in the distribution of the elasticities, as depicted in Figure 1. Yet, since the models are estimated using GLS and taking into account the presence of heteroskedasticity and autocorrelation, it is unlikely that this affects the estimation results. 
A major aim of this paper is to explain the fit of the demand for energy regarding the evolution of prices, conditioned to other determinants of the behavior of agents. In fact, merely taking look at Figure 2 or at any of the components of Figure 3, several relevant matters for the literature in this area become evident. First, energy consumers adapted to price shocks as soon as the first oil crisis took place at the beginning of the 1970s. Second, the second oil crisis a few years later affected energy demand mainly through oil products and natural gas. However, the evolution of electricity consumption closely followed the evolution of GDP and it benefited from decreases in real electricity prices for a long time. Third, even though Figure 3 does not distinguish between different types of energy consumers (available upon request), the evolution of income is the main determinant of their energy demand, particularly in industrial and commercial sectors, and therefore leaves limited possibilities for corrective pricing signals. Fourth, only the 2008 economic crisis has affected aggregate demand (and its components) and this was due to decreases in economic activity rather than to energy price movements. Finally, cross-price effects appear to have the potential to substitute polluting sources in the energy domain. Contrarily, if clean energy sources face price increases, substitution and the limited capacity of demand reduction through prices will both move in a negative environmental direction. It seems therefore that other alternatives, such as information and awareness, should play a role within corrective public policies in this area.

Figure 2. Evolution of crude oil prices 1918-2014 (US\$ of 2012)

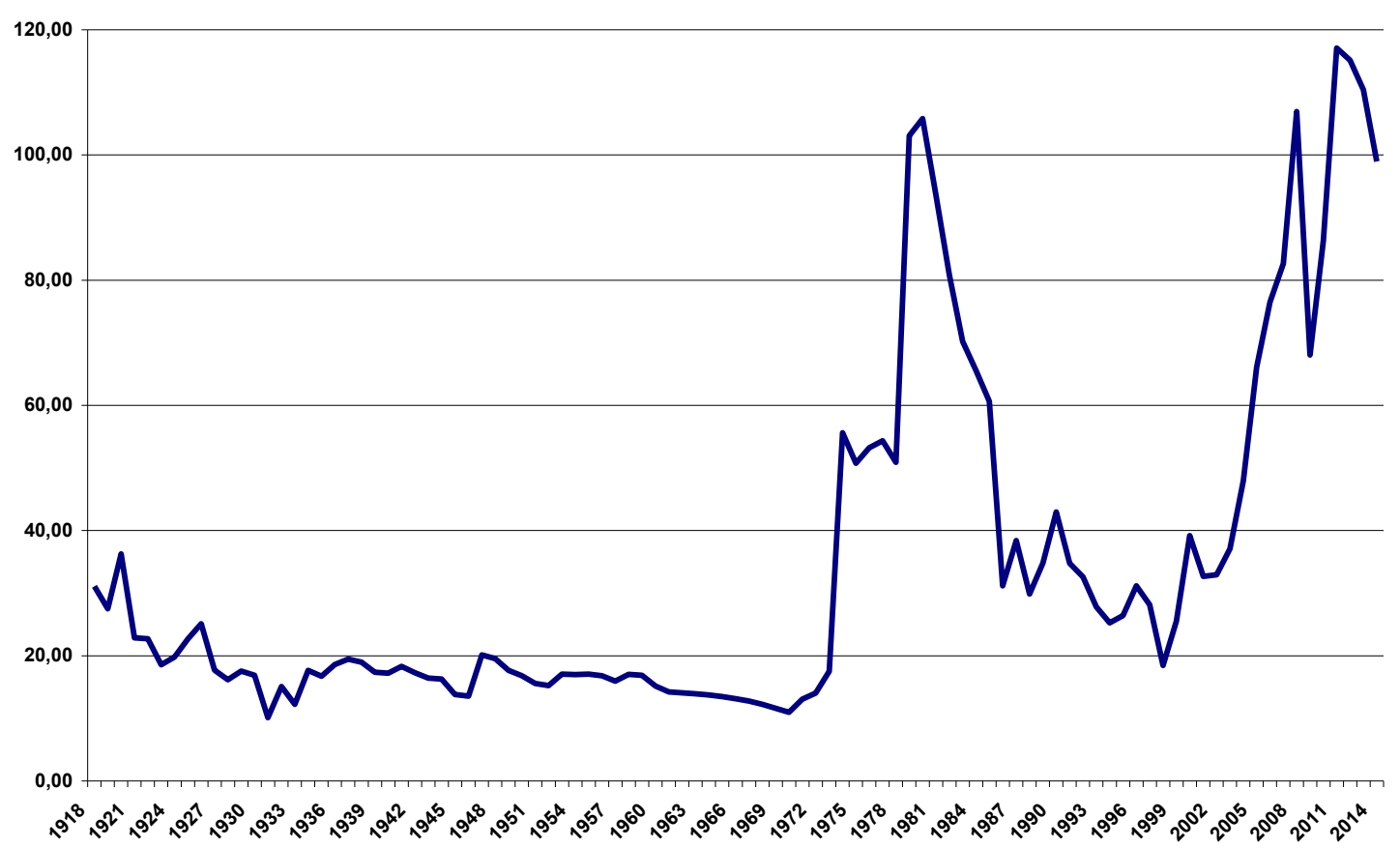

Source: BP (2015) 
Figure 3. GDP, energy consumption and real energy price in the OECD, 1978-2013

$(2010=100)$

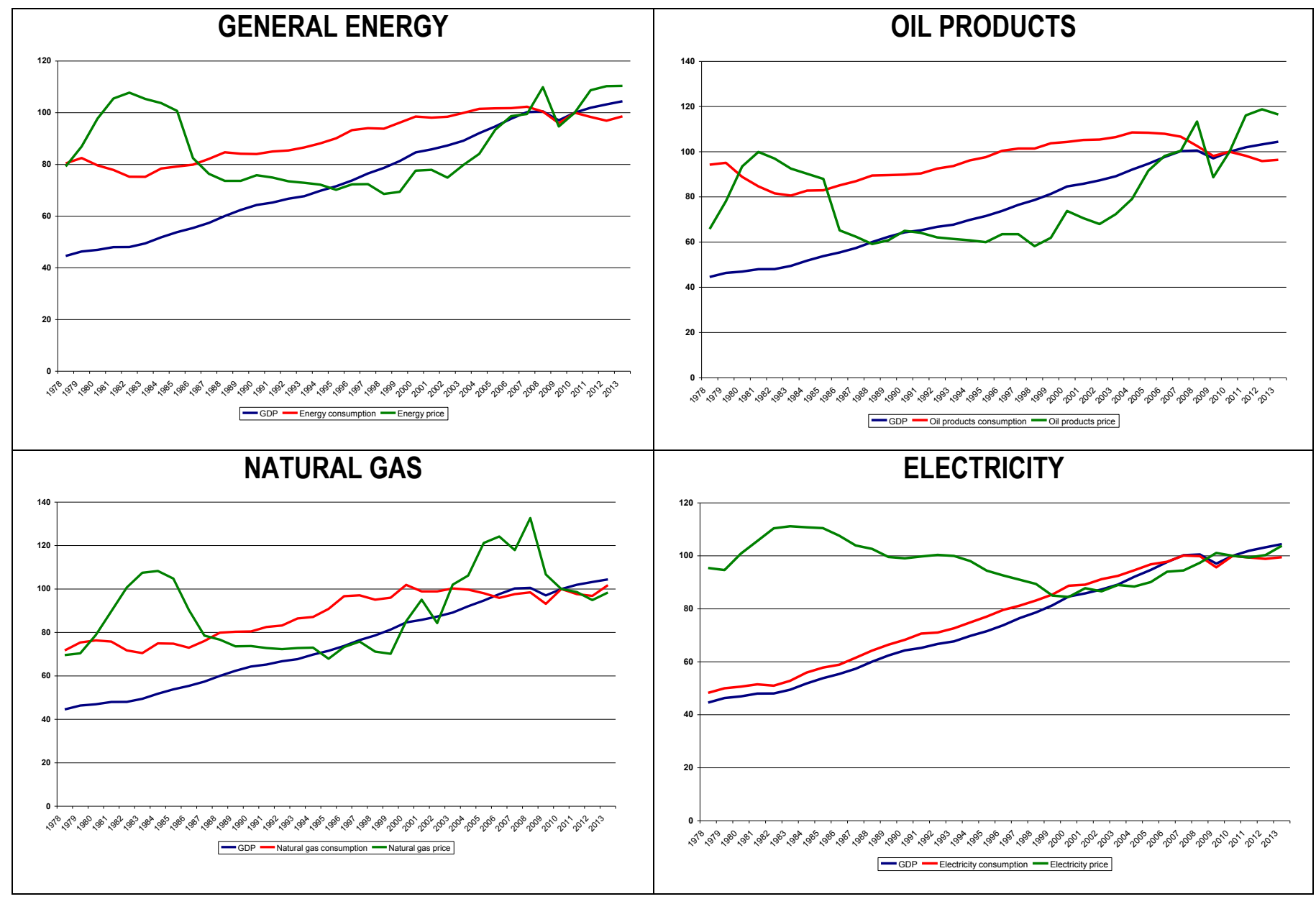

Source: IEA (1999; 2015)

\section{Conclusions}

This paper has conducted a meta-analysis of empirical studies estimating the price elasticity of demand of energy. Unlike previous studies, which particularly focused on specific energy goods (mainly gasoline), the paper considered aggregated energy as well as the demand for the most important energy products: electricity, natural gas, gasoline, diesel and heating oil. Despite the focus of this paper in recent empirical evidence, both the number of considered papers and elasticity estimates are much larger than in previous meta-analyses in the field.

It is clear that a solvent estimation of the price elasticities of energy demand is crucial if we are to understand how shocks in energy prices (policy-related or exogenous) may impact energy 
consumption at an individual (firm or household) level, or growth at an aggregate level, both in the short and long-terms. Besides, insights on the distributional impacts of energy price movements and the related implementation of compensatory policies, subject to an increasing debate in many countries nowadays, would largely benefit from a proper knowledge of price elasticities of energy demand.

The results from this paper show that, on average, the literature has estimated a price elasticity of demand of energy in the short term of -0.22 , and of -0.65 in the long term. Several short-term elasticities of energy products range between -0.26 and -0.20 , while their long-term elasticities range from -0.85 to -0.60 . Except in the case of gasoline demand, already covered by most existing exercises in the area, the results of the paper depict lower short and long-term price elasticities of energy demand than in previous meta-analyses. The main factors influencing the estimates obtained from elasticities in the short term are the type of model used for the study and the type of consumer considered. Indeed, the results indicate that studies with micro models and those employing residential and commercial data lead to significantly higher price elasticities (in absolute terms) than respectively those using aggregate models and industrial data. Regarding long-term elasticities, the most important factors affecting the results are the type of data and model used for the study as well as the type of consumer considered and the fact that the data are previous or subsequent to the 1973 oil crisis. The meta-analysis shows in this case that price elasticities from panel data approaches are significantly higher (lower) than those from time series (cross sections). Moreover, price elasticities are significantly higher when using commercial data on energy demand and when complete demand models are employed, and significantly lower when post-1973 data are used.

It is possible, therefore, to conclude from the meta-analysis results that agents somewhat react to changes in the prices of energy products; this reaction is larger in the long term than it is in the short term and it is quite similar among different energy products. The average values obtained classify energy products as price inelastic, so that pricing policies (through taxation or other regulatory tools) can give rise, ceteris paribus, to a less than proportional reduction in the demand for these goods both in the short and long terms. It is also worth pointing out that the 1973 oil crisis influenced the energy behavior of the agents by forcing them to take steps to reduce their exposure to sharp fluctuations in the prices of energy goods. After that crisis, given the depletion of abatement possibilities, the long-term sensitivity of the agents to changes in the price of energy goods decreased. 
Finally, the results of this paper allow the identification of energy goods in which consumption is more susceptible to price changes, i.e. those goods on which price shocks are likely to have most socio-economic and environmental effects or where corrective pricing policies are potentially more effective. In this sense, heating oil consumption is the most affected by price fluctuations in the short term, while in the long term it is the consumption of natural gas that is the most affected. By contrast, diesel is the least price-sensitive energy good in the short and long terms. In sum, energy and environmental policies that exclusively rely on correcting energy prices may be constrained by the limited price responsiveness shown by this exercise and thus other complementary approaches (information, nudging, etc.) are likely to be necessary in the area. 


\section{References}

BP, 2015. Statistical Review of World Energy 2015. Available at: http://www.bp.com/en/global/corporate/energy-economics/statistical-review-of-world-energy.html

Brons, M., Nijkamp, P., Pels, E., Rietveld, P., 2008. A meta-analysis of the price elasticity of gasoline demand. A SUR approach. Energy Economics, 30, 2105-2122.

Chib, S., Griffiths, W., Koop, G., Terrell, D., 2008. Advances in econometrics. Bayesian econometrics (volume 23). JAI Press, Bingley.

Christensen, L.R., D.W. Jorgenson, Lau, L.J., 1973. Transcendental logarithmic production frontiers, Review of Economics and Statistics, 55, 28-45.

Dahl, C.A., 2012. Measuring global gasoline and diesel price and income elasticities. Energy Policy, 41, 2-13.

Dahl, C.A., 2010. DEDD-G2010.xls in Dahl Energy Demand Database. Available at: http://dahl.mines.edu/courses/dahl/dedd

Dahl, C.A., Sterner, T., 1991. Analysing gasoline demand elasticities: A survey. Energy Economics, 13, 203-210.

Deaton, A.S., Muellbauer, J.N., 1980. An almost ideal demand system. American Economic Review, 83, 570-597.

Engle, R.F., Granger, C.W., 1987. Co-integration and error correction: representation, estimation, and testing. Econometrica, 55, 251-276.

Espey, J.A., Espey, M., 2004. Turning on the lights: a meta-analysis of residential electricity demand elasticities. Journal of Agricultural and Applied Economics, 36, 65-81.

Espey, M., 1998. Gasoline demand revisited: an international meta-analysis of elasticities. Energy Economics, 20, 273-295.

Espey, M., 1996. Explaining the variation in elasticity estimates of gasoline demand in the United States: a meta-analysis. Energy Journal, 17, 49-60.

Glass, G.V., 1976. Primary, secondary, and meta-analysis of research. Educational Researcher, 5, 3-8.

Graham, D., Glaister, S., 2002a. Review of Income and Price Elasticities in the Demand for Road Traffic. Centre for Transport Studies, Imperial College of Science, Technology and Medicine.

Graham, D.J., Glaister, S., 2002b. The demand for automobile fuel. A survey of elasticities. Journal of Transport Economics and Policy, 36, 1-26.

IEA, 2015. Energy Prices and Taxes. Quarterly statistics, fourth quarter 2015. International Energy Agency, Paris.

IEA, 1999. Energy Prices and Taxes. Quarterly statistics, first quarter 1999. International Energy Agency, Paris.

IPCC, 2014. Climate Change 2014: Mitigation of Climate Change. Contribution of Working Group III to the Fifth Assessment Report of the Intergovernmental Panel for Climate Change. Edited by Edenhofer, O. et al. Cambridge University Press, Cambridge.

Hanly, M., Dargay, J., Goodwin, P., 2002. Review of income and price elasticities in the demand for road traffic. ESRC TSU publication 2002/13, Centre for Transport Studies, University of London. 
Härdle, W., Linton, O., 1994. Applied nonparametric methods, in Engle, R.F., McFadden, D. (eds.), Handbook of Econometrics, Volume 4. North Holland, Amsterdam.

Havranek, T., Irsova, Z., Janda, K., 2012. Demand for gasoline is more price-inelastic than commonly thought. Energy Economics, 34, 201-207.

Houthakker, H.S., 1951. Some calculations of electricity consumption in Great Britain. Journal of the Royal Statistical Society. Series A 114, 359-371.

Madlener, R., 1996. Econometric analysis of residential energy demand: a survey. Journal of Energy Literature, 2, 3-32.

Nelson, J.P., Kennedy, P.E., 2009. The use (and abuse) of meta-analysis in environmental and natural resource economics: an assessment. Environmental and Resource Economics, 42, 345-377.

Stanley, T.D., Doucouliagos, H., 2007. Identifying and correcting publication selection bias in the efficiency-wage literature: Heckman meta-regression. SWP 2007/11, Deakin University, Faculty of Business and Law, School of Accounting, Economics and Finance.

Stanley, T.D., Jarrell, S.B., 1989. Meta-regression analysis: a quantitative method of literature surveys. Journal of Economic Surveys, 3, 161-170.

Taylor, L.D., 1975. The demand for electricity: a survey. The Bell Journal of Economics, 6, 74110.

United Nations Development Programme (UNDP), 2015. Human Development Statistical Tables. Available at: http://hdr.undp.org/en/data

Wooldridge, J.M., 2002. Econometric analysis of cross section and panel data. MIT Press, Cambridge.

World Bank, 2015. Energy imports, net (\% of energy use). Available at: http://data.worldbank.org/indicator/EG.IMP.CONS.ZS?page=1 


\section{ANNEX I \\ Parameter Estimates}

Table A1. Parameter estimates for short-term elasticities

\begin{tabular}{|c|c|c|}
\hline Regressor & GLS & Random-effects panel \\
\hline$\hat{\beta}$ & $-0.2196^{* * *}$ & $-0.2237^{* * *}$ \\
\hline Electricity & -0.011 & 0.148 \\
\hline Natural gas & -0.019 & 0.007 \\
\hline Gasoline & $-0.029^{* *}$ & -0.003 \\
\hline Diesel & 0.007 & 0.020 \\
\hline Heating oil & -0.023 & -0.036 \\
\hline Net energy exporter & -0.006 & -0.006 \\
\hline Developing country & -0.008 & -0.019 \\
\hline Post 1973 & $0.059^{* *}$ & 0.030 \\
\hline Post 1979 & 0.014 & 0.039 \\
\hline Post 2008 & 0.013 & -0.018 \\
\hline Residential & -0.007 & $-0.053^{* *}$ \\
\hline Industrial & 0.009 & -0.030 \\
\hline Commercial & $-0.076^{*}$ & $-0.069 * *$ \\
\hline Cross-section & -0.042 & -0.061 \\
\hline Time series & 0.017 & 0.009 \\
\hline Cointegration model & $-0.033^{* *}$ & -0.028 \\
\hline AIDS model & $-0.085^{\star *}$ & $-0.066^{*}$ \\
\hline Micro model & $-0.201^{* * *}$ & $-0.136^{* * *}$ \\
\hline Discrete-continuous model & $-0.105^{* * *}$ & -0.058 \\
\hline No journal & $0.028^{* *}$ & 0.012 \\
\hline Instrumental variables & -0.004 & -0.010 \\
\hline Other estimation methods & 0.015 & 0.028 \\
\hline Joint significance & $\begin{array}{c}F(22,880)=6.20 \\
(p-\text { value }=0.00)\end{array}$ & $\begin{array}{c}\text { Wald } \chi^{2}(22)=75.16 \\
(p-\text { value }=0.00)\end{array}$ \\
\hline $\mathbf{R}^{2}$ & 0.134 & 0.125 \\
\hline
\end{tabular}

Note: ${ }^{* *}$ Significant at the $1 \%$ level; ${ }^{* *}$ at the $5 \%$ level; and ${ }^{*}$ at the $10 \%$ level. 
Table A2. Parameter estimates for long-term elasticities

\begin{tabular}{|c|c|c|}
\hline Regressor & GLS & Random-effects panel \\
\hline$\hat{\beta}$ & $-0.6002^{* * *}$ & $-0.652^{* * *}$ \\
\hline Electricity & $-0.077^{* *}$ & -0.034 \\
\hline Natural gas & $-0.134^{* * *}$ & $-0.198^{* * *}$ \\
\hline Gasoline & $-0.120^{* * *}$ & -0.063 \\
\hline Diesel & -0.020 & 0.057 \\
\hline Heating oil & -0.147 & -0.112 \\
\hline Net energy exporter & -0.024 & -0.024 \\
\hline Developing country & $-0.074^{* * *}$ & -0.034 \\
\hline Post 1973 & $0.114^{*}$ & $0.152^{*}$ \\
\hline Post 1979 & $0.161^{* * *}$ & 0.031 \\
\hline Post 2008 & $0.161^{* *}$ & 0.081 \\
\hline Residential & $-0.085^{* *}$ & -0.037 \\
\hline Industrial & -0.023 & 0.022 \\
\hline Commercial & $-0.298^{* * *}$ & $-0.152^{*}$ \\
\hline Cross-section & $-0.116^{* *}$ & $-0.175^{\star *}$ \\
\hline Time series & $0.109^{* * *}$ & $0.132^{* * *}$ \\
\hline Cointegration model & -0.017 & -0.025 \\
\hline AIDS model & $-0.229^{* * *}$ & $-0.165^{\star *}$ \\
\hline Micro model & -0.001 & -0.024 \\
\hline Discrete-continuous model & -0.080 & -0.198 \\
\hline No journal & 0.032 & 0.065 \\
\hline Instrumental variables & -0.061 & -0.037 \\
\hline Other estimation methods & $-0.087^{\star * *}$ & -0.001 \\
\hline Joint significance & $\begin{array}{c}F(22,916)=38.36 \\
(p-\text { value }=0.00)\end{array}$ & $\begin{array}{c}\text { Wald } \chi^{2}(22)=84.08 \\
\quad(p-\text { value }=0.00)\end{array}$ \\
\hline $\mathbf{R}^{2}$ & 0.479 & 0.196 \\
\hline
\end{tabular}

Note: ${ }^{* * *}$ Significant at the $1 \%$ level; ${ }^{* *}$ at the $5 \%$ level; and ${ }^{*}$ at the $10 \%$ level. 


\section{ANNEX II Papers used in the meta-analysis}

Abeywardena, A., 2002. Transport fuel pricing and taxation in Sri Lanka. South Asia Regional Initiative for Energy (SARI/E) Technical Assistance Program, Seminar on Trade in Cleaner Fuels, Colombo, Sri Lanka, March 9-12.

Adeyemi, O., Broadstock, D.C., 2009. Underlying consumer preferences and their contribution to energy demand. OPEC Energy Review, 33, 198-204.

Adeyemi, O., Hunt, L., 2007. Modelling OECD industrial energy demand: asymmetric price responses and energy-saving technical change. Energy Economics, 29, 693-709.

Adeyemo, 0.O., Mabugu, R., Hassan, R.H., 2007. Inter-fuel substitution: the case of the Nigerian industrial sector. Journal of Energy in Southern Africa, 18, 39-50.

Adofo, Y.O., Evans, J., Hunt, L.C., 2013. How sensitive to time period sampling is the asymmetric price response specification in energy demand modelling? Energy Economics, 40, 90-109.

Agnolucci, P., 2009. The energy demand in the British and German industrial sectors: Heterogeneity and common factors. Energy Economics, 31, 175-187.

Agostini, P., Botteon, M., Carraro, C., 1992. A carbon tax to reduce $\mathrm{CO}_{2}$ emissions in Europe. Energy Economics, 14, 279-290.

Ahmadian, M., Chitnis, M., Hunt, L.C., 2007. Gasoline demand, pricing policy and social welfare in the Islamic Republic of Iran, 31, 105-124.

Ajanovic, A., Haas, R., 2012. The role of efficiency improvements vs. price effects for modeling passenger car transport demand and energy demand. Lessons from European countries. Energy Policy, 41, 36-46.

Akinboade, O., Ziramba, E., Kumo, W., 2008. The demand for gasoline in South Africa: An empirical analysis using co-integration techniques. Energy Economics, 30, 3222-3229.

Akmal, M., Stern, D.I., 2001. Residential energy demand in Australia: an application of dynamic OLS. Woking Papers in Ecological Economics, 104, Centre for Resource and Environmental Studies, The Australian National University.

Al-Azzam, A., Hawdon, D., 1999. Estimating the demand for energy in Jordan: a Stock-Watson dynamic OLS (DOLS) approach. Surrey Energy Economics Discussion paper Series, 97. Surrey Energy Economics Centre, University of Surrey.

Al-Faris, A.F., 2002. The demand for electricity in the GCC countries. Energy Policy, 30, 117-124.

Al-Faris, A.F., 1997. Demand for oil products in the GCC countries. Energy Policy, 25, 55-61.

Al-Rabbaie, A., Hunt, L., 2006. OECD energy demand: modelling underlying energy demand trends using the structural time series model. Surrey Energy Economics Discussion paper Series, 114. Surrey Energy Economics Centre, University of Surrey.

Al-Sahlawi, M., 1997. The demand for oil products in Saudi Arabia. OPEC Review, 21(1), 33-38.

Al-Salman, M.H., 2007. Household demand for energy in Kuwait. Journal of King Saud University, 19, 51 60.

Al-Yousef, N., 2013. Demand for oil products in OPEC countries: a panel cointegration analysis. International Journal of Energy Economics and Policy, 3, 168-177.

Alberini, A., Filippini, M., 2011. Response of residential electricity demand to price: The effect of measurement error. Energy Economics, 33, 889-895.

Alberini, A., Gans, W., Velez-Lopez, D., 2011. Residential consumption of gas and electricity in the U.S: The role of prices and income. Energy Economics, 33, 870-881. 
Allen, C., Urga, G., 1999. Interrelated factor demands from dynamic cost functions: an application to the non-energy business sector of the UK economy. Economica, 66, 403-413.

Alter, N., Syed, S.H., 2011. An empirical analysis of electricity demand in Pakistan. International Journal of Energy Economics and Policy, 1, 116-139.

Alves, D.C., Bueno, R.L., 2003. Short-run, long-run and cross elasticities of gasoline demand in Brazil. Energy Economics, 25, 191-199.

Amarawickrama, H.A., Hunt, L.C., 2008. Electricity demand for Sri Lanka: A time series analysis. Energy, 33, 724-739.

Amato, A.D., Ruth, M., Kirshen, P., Horwitz, J., 2005. Regional energy demand responses to climate change: Methodology and application to the commonwealth of Massachusetts. Climatic Change, 71, 175201.

Amengual, D., Cubas, G., 2002. Imposición óptima a las naftas y el gasoil. Un análisis empírico para Uruguay (1988-2001). XVII Jornada Anual de Economía, Banco Central de Reserva de Uruguay.

Andersen, T.B., Nilsen, O.B., Tveteras, R., 2011. How is demand for natural gas determined across European industrial sectors? Energy Policy, 39, 5499-5508.

Ang, B.W., Goh, T.N., Liu, X.Q., 1992. Residential electricity demand in Singapore. Energy, 17, 37-46.

Arisoy, I., Ozturk, I., 2014. Estimating industrial and residential electricity demand in Turkey. A time varying parameter approach. Energy, 66, 959-964.

Aroonruengsawat, A., Auffhammer, M., Sanstad, A.H., 2012. The impact of state level building codes on residential electricity consumption. Energy Journal, 33, 31-52.

Arora, V., 2014. Estimates of the price elasticities of natural gas supply and demand in the United States. MPRA Paper, 54232.

Arsenault, E., Bernard, J.T., Carr, C.W., Genest-Laplante, E., 1995. A total energy demand model of Québec. Energy Economics, 17, 163-171.

Arthur, M.F.S.R., Bond, C.A., Willson, B., 2012. Estimation of elasticities for domestic energy demand in Mozambique. Energy Economics, 34, 398-409.

Asadoorian, M., Eckaus, R., Schlosser, A., 2008. Modeling climate feedbacks to electricity demand: The case of China. Energy Economics, 30, 1577-1602.

Asche, F., Nilsen, O., Tveteras, R., 2008. Natural gas demand in the European household sector. Energy Journal, 29, 27-46.

Asensio, J., Gómez-Lobo, A., Matas, A., 2014. How effective are policies to reduce gasoline consumption? Evaluating a set of measures in Spain. Energy Economics, 42, 34-42.

Atakhanova, Z., Howie, P., 2007. Electricity demand in Kazakhstan. Energy Policy, 35, 3729-3743.

Athukorala, P.P., Wilson, C., 2010. Estimating short and long-term residential demand for electricity: New evidence from Sri Lanka. Energy Economics, 32, S34-S40.

Azevedo, I.M., Morgan, M.G., Lave, L., 2011. Residential and regional electricity consumption in the U.S. and EU: how much will higher prices reduce $\mathrm{CO}_{2}$ emissions? Electricity Journal, 24, 21-29.

Badri, M.A., 1992. Analysis of demand for electricity in the United States. Energy, 17, 725-733.

Baker, P., Blundell, R., 1991. The microeconometric approach to modelling energy demand: some results for UK households. Oxford Review of Economic Policy, 7, 54-76.

Bakhat, M., Labeaga, J.M., Labandeira, X., López-Otero, X., 2013. Economic crisis and elasticities of car fuels: evidence for Spain. WP FA15/2013, Economics for Energy.

Bakhat, M., Rosselló, J., 2013. Evaluating a seasonal fuel tax in a mass tourism destination: a case study for the Balearic Islands. Energy Economics, 38, 12-18. 
Baltagi, B.H., Bresson, G., Griffin, J.M., Pirotte, A., 2003. Homogeneous, heterogeneous or shrinkage estimators? Some empirical evidence from French regional gasoline consumption. Empirical Economics, 28, 795-811.

Baltagi, B.H., Griffin, J.M., 1997. Pooled estimators vs. their heterogeneous counterparts in the context of dynamic demand for gasoline. Journal of Econometrics, 77, 303-327.

Banaszak, S., Chakravorty, U., Leung, P., 1999. Demand for ground transportation fuel and pricing policy in Asian tigers: A comparative study of Korea and Taiwan. Energy Journal, 20, 145-165.

Banfi, S., Filippini M., Hunt, L., 2005. Fuel tourism in border regions: the case of Switzerland. Energy Economics, 27, 689-707.

Banks, J., Blundell, R., Lewbel, A., 1997. Quadratic Engel curves and consumer demand. Review of Economics and Statistics, 79, 527-539.

Baranzini, A., Weber, S., 2013. Elasticities of gasoline demand in Switzerland. Energy Policy, 63, 674-680.

Barla, P., Gilbert-Gonthier, M., Tagne Kuelah, J.-R., 2014. The demand for road diesel in Canada. Energy Economics, 43, 316-322.

Beenstock, K.M., Goldin, E., Nabot, D., 1999. The demand for electricity in Israel. Energy Economics, 21, 168-183.

Bekhet, H.A., Othman, N.S., 2011. Assessing the elasticities of electricity consumption for rural and urban areas in Malaysia: A non-linear approach. International Journal of Economics and Finance, 3, 208-217.

Belhaj, M., 2002. Vehicle and fuel demand in Morocco. Energy Policy, 30, 1163-1171.

Belke, A., Dobnik, F., Dreger, C., 2011. Energy consumption and economic growth: New insights into the cointegration relationship. Energy Economics, 33, 782-789.

Ben Sita, B., Marrouch, W., Abosedra, S., 2012. Short-run price and income elasticity of gasoline demand: Evidence from Lebanon. Energy Policy, 46, 109-115.

Benavente, J.M., Galetovic, A., Sanhueza, R., Serra, P., 2005. Estimando la demanda residencial por electricidad en Chile: el consumo es sensible al precio. Cuadernos de Economía, 42, 31-61.

Bentzen, J., 1994. An empirical analysis of gasoline demand in Denmark using cointegration techniques. Energy Economics, 16, 139-143.

Bentzen, J., Engsted, T., 2001. A revival of the autoregressive distributed lag model in estimating energy demand relationships. Energy, 26, 45-55.

Bentzen, J., Engsted, T., 1993. Short- and long-run elasticities in energy demand: A cointegration approach. Energy Economics, 15, 9-16.

Berkhout, P., Ferrer-Carbonell, A., Muskens, J., 2004. The ex post impact of an energy tax on household energy demand. Energy Economics, 26, 297-317.

Berkowitz, M.K., Gallini, N.T., Miller, E.J., Wolfe, R.A., 1990. Disaggregate analysis of the demand for gasoline. Canadian Journal of Economics, 23, 253-275.

Bernard, J.T., 1996. An integrated total energy demand model for the province of Québec. Département d'économie, Université Laval.

Bernard, J.T., Bolduc, D., Bélanger, D., 1996. Quebec residential electricity demand: A microeconomic approach Canadian Journal of Economics, 29, 92-113.

Bernard, J. T., Bolduc, D., Yameogo, N. D., 2011. A pseudo-panel data model of household electricity demand. Resource and Energy Economics, 33, 315-325.

Bernstein, M.A., Griffin, J., 2005. Regional Differences in the Price-elasticity of Demand for Energy. RAND Technical Report.

Bernstein, R., Madlener, R., 2011a. Responsiveness of residential electricity demand in OECD countries: A panel cointegration and causality analysis. FCN Working Paper, 8/2011. 
Bernstein, R., Madlener, R., 2011b. Residential natural gas demand elasticities in OECD countries: An ARDL bounds testing approach. FCN Working Paper, 15/2011.

Bernstein, R., Madlener, R., 2010. Short- and long-run electricity demand elasticities at the subsectoral level: A cointegration analysis for German manufacturing industries. FCN Working Paper, 19/2010.

Beznoska, M., 2014. Estimating a consumer demand system of energy, mobility and leisure: A microdata approach for Germany. Discussion Paper, School of Business \& Economics: Economics, 2014/8, Freie Universität Berlin.

Bhattacharyya, S.C., Blake, A., 2009. Domestic demand for petroleum products in MENA countries. Energy Policy, 37, 1552-1560.

Bianco, V., Manca, O., Nardini, S., 2009. Electricity consumption forecasting in Italy using linear regression models. Energy, 34, 1413-1421.

Bianco, V., Manca, O., Nardini, S., Minea, A.A., 2010. Analysis and forecasting of nonresidential electricity consumption in Romania. Applied Energy, 87, 3584-3590.

Bianco, V., Scarpa, F., Tagliafico, L.A., 2014. Scenario analysis of nonresidential natural gas consumption in Italy. Applied Energy, 113, 392-403.

Bigano, A., Borsello, F., Marano, G., 2006. Energy demand and temperature: A dynamic panel analysis. Nota di Lavoro, 112, Fondazione Eni Enrico Mattei.

Bigerna, S., Bollino, C.A., 2014. Electricity demand in wholesale Italian market. Energy Journal, 35, 25-46.

Bilgili, F., Pamuk, Y., Tülüce, N., 2010. Short run and long run dynamics of residential electricity consumption: Homogeneous and heterogeneous panel estimations for OECD. MPRA Paper, 33291.

Birol, F., Guerer, N., 1993. Modelling the transport sector fuel demand for developing economies. Energy Policy, 21, 1164-1172.

Bjørner, T., Jensen, H., 2002a. Energy taxes, voluntary agreements and investment subsidies. A micropanel analysis of the effect on Danish industrial companies' energy demand. Resource and Energy Economics, 24, 229-249.

Bjørner, T., Jensen, H., 2002b. Inter-fuel substitution within industrial companies: An analysis based on panel data at company level. Energy Journal, 23, 27-50.

Bjørner, T., Togeby, M., Jensen, H., 2001. Industrial companies' demand for electricity: Evidence from a micropanel. Energy Economics, 23, 595-617.

Blázquez, L., Boogen, N., Filippini, M., 2013a. Residential electricity demand in Spain: new empirical evidence using aggregate data. Energy Economics, 36, 648-657.

Blázquez, L., Filippini, M., Heimsch, F., 2013b. Regional impact of changes in disposable income on Spanish electricity demand: A spatial econometric analysis. Energy Economics, 40, S58-S66.

Blundell, R., Robin, JM., 1999. Estimation in large and disaggregated demand systems: An estimator for conditionally linear systems. Journal of Applied Econometrics, 14, 209-232.

Bölük, G., Koç, A.A., 2010. Electricity demand of manufacturing sector in Turkey: A translog cost approach. Energy Economics, 32, 609-615.

Borenstein, S., 2009. To what electricity price do consumers respond? Residential demand elasticity under increasing-block pricing. Working Paper, University of California, Berkeley.

Borges, A.M., Pereira, A.M., 1992. Energy demand in Portuguese manufacturing: A two-stage model. Energy, 17, 61-77.

Bose, R.K., Shukla, M., 1999. Elasticities of electricity demand in India. Energy Policy, 27, 137-146.

Boshoff, W.H., 2012. Gasoline, diesel fuel and jet fuel demand in South Africa. Journal for Studies in Economics and Econometrics, 36, 43-78. 
Branch, E., 1993. Short run income elasticity of demand for residential electricity using consumer expenditure survey data. Energy Journal, 14, 111-122.

Brännlund, R., 2013. The effects on energy saving from taxes on motor fuels: The Swedish case. CERE Working Paper, 06-2013.

Brännlund, R., Ghalwash, T., Nordström, J., 2007. Increased energy efficiency and the rebound effect: Effects on consumption and emissions. Energy Economics, 29, 1-17.

Brenton, P., 1997. Estimates of the demand for energy using cross-country consumption data. Applied Economics, 29, 851-859.

Broadstock, D.C., Collins, A., Hunt, L.C., 2011. Transportation oil demand, consumer preferences and asymmetric prices. Journal of Economic Studies, 38, 528-536.

Burke, P.J., Nishitateno, S., 2013. Gasoline prices, gasoline consumption, and new-vehicle fuel economy: Evidence for a large sample of countries. Energy Economics, 36, 363-370.

Burnquist, H., Bacchi, M., 2002. A demanda por gasolina no Brasil: uma analise utilizando tecnicas de cointegracao. Congresso da Sociedade Brasileira de Economia e Sociologia Rural, Passo Fundo.

BuShehri, M., Wohlgenant, M., 2012. Measuring the welfare effects of reducing a subsidy on a commodity using micro-models: An application to Kuwait's residential demand for electricity. Energy Economics, 34, 419-425.

Bushnell, J.B., Mansur, E.T., 2005. Consumption under noisy price signals: a study of electricity retail rate deregulation in San Diego. Journal of Industrial Economics, 53, 493-513.

Carter, A., Craigwell, R., Moore, W., 2012. Price reform and household demand for electricity. Journal of Policy Modeling, 34, 242-252.

Casarin, A.A., Delfino, M.E., 2011. Price freezes, durables, and residential electricity demand. Evidence from Greater Buenos Aires. Energy Economics, 33, 859-869.

Casler, S.D., 1997. Applied production theory: Explicit, flexible, and general functional forms. Applied Economics, 29, 1483-1492.

Cebula, R.J., Herder, N., 2010. An empirical analysis of determinants of commercial and industrial electricity consumption. Business and Economics Journal, 2010, 1-7.

Chakravorty, U., Fesharaki, F., Zhou, S., 2000. Domestic demand for petroleum in OPEC countries. OPEC Review, 24, 23-53.

Chama, C.Y., 2012. An econometric analysis of Zambian industrial electricity demand. Dissertation, M.Phil in Environmental and Development Economics. Department of Economics, University of Oslo.

Chan, H.L., Lee, S.K., 1996. Forecasting the demand for energy in China. Energy Journal, 17, 19-30.

Chandrasiri, S., 2006. Demand for road-fuel in a small developing economy: The case of Sri Lanka. Energy Policy, 34, 1833-1840.

Chang, D., Serletis, A., 2014. The demand for gasoline: Evidence from household survey data. Journal of Applied Econometrics, 29, 291-313.

Chang, H.S., Hsing, Y., 1991. The demand for residential electricity: New evidence on time-varying elasticities. Applied Economics, 23, 1251-1256.

Chang, Y., Martinez-Chambo, E., 2003. Electricity demand analysis using cointegration and errorcorrection models with time varying parameters: The Mexican case. Working paper, 2003-08, Rice University.

Chaudhary, M., Ahmad, E., Burki, A., Khan, M., 1999. Industrial sector input demand responsiveness and policy interventions. Pakistan Development Review, 38, 1083-1100.

Chaudhry, A.A., 2010. A panel data analysis of electricity demand in Pakistan. Lahore Journal of Economics, 15, 75-106. 
Cheung, K.Y., Thomson, E., 2004. The demand for gasoline in China: A cointegration analysis. Journal of Applied Statistics, 31, 533-544.

Chitnis, M., Hunt, L.C., 2012. What drives the change in UK household energy expenditure and associated $\mathrm{CO}_{2}$ emissions? Implication and forecast to 2020. Applied Energy, 94, 202-214.

Christodoulakis, N.M., Kalyvitis, S.C., 1997. The demand for energy in Greece: Assessing the effects of the Community Support Framework 1994-1999. Energy Economics, 19, 393-416.

Christodoulakis, N.M., Kalyvitis, S.C., Lalas, D.P., Pesmajoglou, S., 2000. Forecasting energy consumption and energy related $\mathrm{CO}_{2}$ emissions in Greece: An evaluation of the consequences of the Community Support Framework II and natural gas penetration. Energy Economics, 22, 395-422.

Christopoulos, D., 2000. The demand for energy in Greek manufacturing. Energy Economics, 22, 569586.

Christopoulos, D., Tsionas, E., 2002. Allocative inefficiency and the capital-energy controversy. Energy Economics, 24, 305-318.

Considine, T. 2000. The impacts of weather variations on energy demand and carbon emissions. Resources and Energy Economics, 22, 295-312.

Costa, D.L., Kahn, M.E., 2011. Electricity consumption and durable housing: Understanding cohort effects. American Economic Review, 101, 88-92.

Costa, D.L., Kahn, M.E., 2010. Why has California's residential electricity consumption been so flat since the 1980s? A microeconometric approach. NBER Working Paper Series, 15978.

Coyle, D., DeBacker, J., Prisinzano, R., 2012. Estimating the supply and demand of gasoline using tax data. Energy Economics, 34, 195-200.

Crôtte, A., Noland, R., Graham, D., 2010. An analysis of gasoline demand elasticities at the national and local levels in Mexico. Energy Policy, 38, 4445-4456.

Dagher, L., 2012. Natural gas demand at the utility level: An application of dynamic elasticities. Energy Economics, 34, 961-969.

Dahan, A.A., 1996. Energy consumption in Yemen. Economics and policy (1970-1990). Ph.D. Dissertation, Department of Mining and Geological Engineering, University of Arizona.

Dahl, C., Erdogan, M., 2000. Energy and inter-factor substitution in Turkey. OPEC Review, 24, 1-22.

Dahl, C., Kurtubi, 2001. Estimating oil product demand in Indonesia using a co-integration error correction model. OPEC review, 25, 1-21.

Danesin, A., Linares, P., 2012. An estimation of fuel demand elasticities for Spain: An aggregated panel approach accounting for diesel share. 7th Conference of the Spanish Association for Energy Economics.

Dargay, J., 1992. The irreversible effects of high oil prices: Empirical evidence for the demand for motor fuels in France, Germany, and the U.K. In Hawdon, D. (ed.), Energy Demand: Evidence and Expectations. Surrey University Press, New York.

Dargay, J, Gately, D, 1997. The demand for transportation fuels: Imperfect price-reversibility? Transportation Research B, 31, 71-82.

Davis, L., Kilian, L., 2011. The allocative cost of price ceilings in the U.S. residential market for natural gas. Journal of Political Economy, 119, 212-241.

Davis, L., Muehlegger, E., 2010. Do Americans consume too little natural gas? An empirical test of marginal cost pricing. RAND Journal of Economics, 41, 791-810.

De Cian, E., Lanzi, E., Roson, R., 2007. The impact of temperature change on energy demand: A dynamic panel analysis. Nota di Lavoro, 46-2007, Fondazione Eni Enrico Mattei.

De Vita, G., Endresen, K., Hunt, L.C., 2006. An empirical analysis of energy demand in Namibia. Energy Policy, 34, 3447-3463. 
Delfino, J.A., 1995. La demanda industrial de energía. Una estimación integral por etapas. Económica, 41, 125-149.

Denton, F.T., Mountain, D.C., Spencer, B.G., 2003. Energy demand with declining rate schedules: an econometric model for the U.S. commercial sector. Land Economics, 79, 86-105.

Denton, F.T., Mountain, D.C., Spencer, B.G., 2000. Energy use in the commercial sector: estimated intensities and costs for Canada based on US survery data. Energy Studies Review, 9, 24-46.

Dergiades, T., Tsoulfidis, L., 2008. Estimating residential demand for electricity in the United States, 19652006. Energy Economics, 30, 2722-2730.

Di Cosmo, V., Hyland, M., 2013. Carbon tax scenarios and their effects on the Irish energy sector. Energy Policy, 59, 404-414.

Diabi, A., 1998. The demand for electric energy in Saudi Arabia: An empirical investigation. OPEC Review, 22, 13-29.

Dicembrino, C., Trovato, G., 2013. Structural breaks, price and income elasticity and forecast of the monthly Italian electricity demand. 10th International Conference on the European Energy Market.

Dilaver, Z., Hunt, L.C., 2011a. Industrial electricity demand for Turkey: A structural time series analysis. Energy Economics, 33, 426-436.

Dilaver, Z., Hunt, L.C., 2011b. Modelling and forecasting Turkish residential electricity demand. Energy Policy, 39, 3117-3127.

Dilaver, Z., Hunt, L.C., 2011c. Turkish aggregate electricity demand: An outlook to 2020. Energy, 36, 6686-6696.

Dimitropoulos, J., Hunt, L., Judge, G., 2005. Estimating underlying energy demand trends using UK annual data. Applied Economics Letters, 12, 239-244.

Dodgson, J.S., Millward, R., Ward, R., 1990. The decline in residential electricity consumption in England and Wales. Applied Economics, 22, 59-68.

Donatos, G.S., Mergos, G.J., 1991. Residential demand for electricity: The case of Greece. Energy Economics, 13, 41-47.

Dulleck, U., Kaufmann, S., 2004. Do customer information programs reduce household electricity demand? The Irish program. Energy Policy, 32, 1025-1032.

Dumagan, J.C., Mount, T.D., 1993. Welfare effects of improving end-use efficiency: Theory and application to residential electricity demand. Resource and Energy Economics, 15, 175-201.

Durant, I., 1990. The residential demand for electricity in Barbados: 1966-1988. Research Department, Central Bank of Barbados.

Egorova, S., Volchkova, N., 2004. Sectoral and regional analysis of industrial electricity demand in Russia. New Economic School Working Paper.

El-Shazly, A., 2013. Electricity demand analysis and forecasting: A panel cointegration approach. Energy Economics, 40, 251-258.

Elkhafif, M.A.T., 1992. Estimating disaggregated price elasticities in industrial energy demand. Energy Journal, 13, 209-217.

Eltony, M.N., 2006. Industrial energy policy: a case study of demand in Kuwait. OPEC Review, 30, 85-103.

Eltony, M.N., 1999. Transport demand for energy: A case study for Kuwait. International Journal of Energy Resources, 23, 151-156.

Eltony, M.N., 1996a. Demand for gasoline in the GCC: An application of pooling and testing procedures. Energy Economics, 18, 203-209.

Eltony, M.N., 1996b. Demand for natural gas in Kuwait: An empirical analysis using two econometric models. International Journal of Energy Research, 20, 957-963. 
Eltony, M.N., 1993. Transport gasoline demand in Canada. Journal of Transport Economics and Policy, 27, 193-208.

Eltony, M.N., Al-Awadhi, M.A., 2007. The commercial sector demand for energy in Kuwait. OPEC Review, $31,17-26$.

Eltony, M.N., Al-Mutairi, N.H., 1995. Demand for gasoline in Kuwait. An empirical analysis using cointegration techniques. Energy Economics, 17, 249-253.

Eltony, M.N., Hajeed, M., 1999a. Electricity demand by the commercial sector in Kuwait: An econometric analysis. OPEC Review, 23, 23-32.

Eltony, M.N., Hajeed, M., 1999b. Household energy demand in Kuwait: an integrated two-level approach. OPEC Review, 23, 293-301.

Erdogdu, E., 2014. Motor fuel prices in Turkey. Energy Policy, 69, 143-153.

Erdogdu, E., 2010. Natural gas demand in Turkey. Applied Energy, 87, 211-219.

Erdogdu, E., 2007. Electricity demand analysis using cointegration and ARIMA modelling: A case study of Turkey. Energy Policy, 35, 1129-1146.

Eskeland, G., Feyzioglu, T., 1997a. Is demand for polluting goods manageable? An econometric study of car ownership and use in Mexico. Journal of Development Economics, 53, 423-445.

Eskeland, G., Feyzioglu, T., 1997b. Rationing can backfire: The "day without car" in Mexico City. The World Bank Economic Review, 11, 383-408.

Eskeland, G., Jimenez, E., Lili, L., 1994. Energy pricing and air pollution. Econometric evidence from manufacturing in Chile and Indonesia. Policy Research Working Paper 1323, The World Bank.

Espino, J.M., 2005. Estimación de la elasticidad de la demanda de gasolina en México, 1993-2003. Documents de Recerca, Economía Aplicada. Universitat Autónoma de Barcelona.

Fan, S., Hyndman, R., 2011. The price elasticity of electricity demand in South Australia. Energy Policy, 39, 3709-3719.

Faruqui, A., Sergici, S., 2011. Dynamic pricing of electricity in the mid-Atlantic region: Econometric results from the Baltimore gas and electric company experiment. Journal of Regulatory Economics, 40, 82-109.

Fatai, K., Oxley, L., Scrimgeour, F.G., 2003. Modeling and forecasting the demand for electricity in New Zealand: A comparison of alternative approaches. Energy Journal, 24, 75-102.

Fell, H., Li, S., Paul, A., 2014. A new look at residential electricity demand using household expenditure data. International Journal of Industrial Organization, 33, 37-47.

Feng, Y., Fullerton, D., Gan, L., 2013. Vehicle choices, miles driven, and pollution policies. Journal of Regulatory Economics, 44, 4-29.

Filippini, M., 2011. Short- and long-run time-of-use price elasticities in Swiss residential electricity demand. Energy Policy, 39, 5811-5817.

Filippini, M., 1999. Swiss residential demand for electricity. Applied Economics Letters, 6, 533-538.

Filippini, M., 1995a. Electricity demand by time of use. An application of the household AIDS model. Energy Economics, 17, 197-204.

Filippini, M., 1995b. Swiss residential demand for electricity by time-of-use. Resource and Energy Economics, 17, 281-290.

Filippini, M., 1995c. Swiss residential demand for electricity by time-of-use: An application of the almost ideal demand system. Energy Journal, 16, 27-40.

Filippini, M., Hunt, L., 2011. Energy demand and energy efficiency in the OECD countries: A stochastic demand frontier approach. Energy Journal, 32, 59-80. 
Filippini, M., Pachauri, S., 2004. Elasticities of electricity demand in urban Indian households. Energy Policy, 32, 429-436.

Flood, L., Islam, N., Sterner, T., 2010. Are demand elasticities affected by politically determined tax levels? Applied Economics Letters, 17, 325-328.

Floros, N., Vlachou, A., 2005. Energy demand and energy-related $\mathrm{CO}_{2}$ emissions in Greek manufacturing: Assessing the impact of a carbon tax. Energy Economics, 27, 387-413.

Fouquet, R., 1995. The impact of VAT introduction on UK residential energy demand. An investigation using the cointegration approach. Energy Economics, 17, 237-245.

Friesen, J., 1992. Testing dynamic specification of factor demand equations for U.S. manufacturing. Review of Economics and Statistics, 74, 240-250.

Frondel, M., Peters, J., Vance, C., 2008. Identifying the rebound: Evidence from a German household panel. Energy Journal, 29, 145-163.

Frondel, M., Vance, C., 2014. More pain at the diesel pump? An econometric comparison of diesel and petrol price elasticities. Journal of Transport Economics and Policy, 48, 449-463.

Frondel, M., Vance, C., 2010. Driving for fun? Comparing the effect of fuel prices on weekday and weekend fuel consumption. Energy Economics, 32, 102-109.

Fullerton, T.M., Juarez, D.A., Walke, A.G., 2012. Residential electricity consumption in Seattle. Energy Economics, 34, 1693-1699.

Gabreyohannes, E., 2010. A non-linear approach to modelling the residential electricity consumption in Ethiopia. Energy Economics, 32, 515-523.

Galindo, L.M., 2005. Short- and long-run demand for energy in Mexico: A cointegration approach. Energy Policy, 33, 1179-1185.

Galindo, L.M., Salinas, E., 1997. La demanda de gasolinas en México, la condición de exogeneidad y el comportamiento de los agentes económicos, en Instituto Nacional de Ecología (ed.), Instrumentos Económicos y Medio Ambiente. Dirección General de Regulación Ambiental, Instituto Nacional de Ecología, México.

Gallardo, J., Bendezú, L., Coronado, J., 2004. Estimación de la demanda agregada de electricidad. Documento de Trabajo 4, Oficina de Estudios Económicos, OSINERG.

Galli, R., 1998. The relationship between energy intensity and income levels: Forecasting long term energy demand in Asian emerging countries. Energy Journal, 19, 85-105

Gam, I., Ben Rejeb, J., 2012. Electricity demand in Tunisia. Energy Policy, 45, 714-720.

Garcia-Cerrutti, L.M., 2000. Estimating elasticities of residential energy demand from panel county data using dynamic random variables models with heteroskedastic and correlated error terms. Resource and Energy Economics, 22, 355-366.

Gately, 1993. Oil demand in the US and Japan: Why the demand reductions caused by the price increases of the 1970's won't be reversed by the price declines of the 1980's. Japan and the World Economy, 5, 295-320.

Gately, D., 1992. Imperfect price-reversibility of U.S. gasoline demand: Asymmetric responses to price increases and declines. Energy Journal, 13, 179-208.

Gately, D., Huntington, H.G., 2002. The asymmetric effects of changes in price and income on energy and oil demand. Energy Journal, 23, 19-37.

Gately, D., Streifel, S., 1997. Demand for oil products in developing countries. World Bank Discussion Paper 359.

Ghaderi, S.F., Azadeh, M.A., Mohammadzadeh, S., 2006. Electricity demand function for the industries of Iran. Information Technology Journal, 5, 401-404. 
Goel, R., Morey, M., 1993. Effect of the 1973 oil price embargo: A non-parametric analysis. Energy Economics, 15, 39-48.

Goldberg, P.K., 1998. The effects of the corporate average fuel efficiency standards in the US. The Journal of Industrial Economics, 46, 1-33.

González-Marrero, R.N., Lorenzo-Alegría, R.M., Marrero, G.A., 2012. A dynamic model for road gasoline and diesel consumption: An application for Spanish regions. International Journal of Energy Economics and Policy, 2, 201-209.

Greening, L.A., Jeng, H.T., Formby, J.P., Cheng, D.C., 1995. Use of region, life-cycle and role variables in the short-run estimation of the demand for gasoline and miles travelled. Applied Economics, 27, 643-656.

Grifin, J.M., Schulman, C.T., 2005. Price asymmetry in energy demand models: A proxy for energy-saving technical change? Energy Journal, 26, 1-21.

Gundimeda, H., Köhlin, G., 2008. Fuel demand elasticities for energy and environmental policies: Indian sample survey evidence. Energy Economics, 30, 517-546.

Guo, C., Tybout, J.R., 1994. How relative prices affect fuel use patterns in manufacturing. Plant-level evidence from Chile. Policy Research Working Paper 1297, World Bank.

Haas, R., Biermayr, P., Zoechling, J., Auer, H., 1998. Impacts on electricity consumption of household appliances in Austria: A comparison of time series and cross-section analyses. Energy Policy, 26, 10311040.

Haas, R., Schipper, L., 1998. Residential energy demand in OECD-countries and the role of irreversible efficiency improvements. Energy Economics, 20, 421-442.

Halicioglu, F., 2007. Residential electricity demand dynamics in Turkey. Energy Economics, 29, 199-210.

Halvorsen, B., Larsen, B., 2001a. Norwegian residential electricity demand. A microeconomic assessment of the growth from 1976 to 1993. Energy Policy, 29, 227-236.

Halvorsen, B., Larsen, B., 2001b. The flexibility of household electricity demand over time. Resource and Energy Economics, 23, 1-18.

Ham, J.C., Mountain, D.C., Chan, M.W.L., 1997. Time-of-use prices and electricity demand: Allowing for selection bias in experimental data. RAND Journal of Economics, 28, S113-S141.

Hanemann, M., Labandeira, X., Labeaga, J.M., López-Otero, X., 2013. Energy demand for heating: short run and long run. WP 07/2013, Economics for Energy.

Hansen, P.V., 2004. Regional electricity spot price responses in Norway. Statistics Norway Research Department, 2004/13.

Haro, R., Ibarrola, J., 2000. Cálculo de la elasticidad precio de la demanda de gasolina en la zona fronteriza norte de México. Gaceta de Economía, 6, 237-262.

Harvey, A.C., Marshall, P., 1991. Inter-fuel substitution, technical change and the demand for energy in the UK economy. Applied Economics, 23, 1077-1086.

Haughton, J., Sarkar, S., 1996. Gasoline tax as a corrective tax: Estimates for the United States 19701991. Energy Journal, 17, 103-126.

Hausman, J., Newey, W., 1995. Nonparametric estimation of exact consumer surplus and deadweight loss. Econometrica, 63, 1445-1465.

Henley, A., Peirson, J., 1998. Residential energy demand and the interaction of price and temperature: British experimental evidence. Energy Economics, 20, 157-171.

Herbert, J.H., 1990. Multiple comparison procedures and the analysis of natural gas demand behavior. Journal of Economic and Social Measurement, 16, 137-148.

Hill, C., Cao, K., 2013. Energy use in the Australian manufacturing industry: An analysis of energy demand elasticity. Australian Bureau of Statistics, Analytical Services Branch. 
Hisnanick, J.J., Kyer, B.L., 1995. Assessing a disaggregated energy input. Using confidence intervals around translog elasticity estimates. Energy Economics, 17, 125-132.

Holtedahl, P., Joutz, F. L., 2004. Residential electricity demand in Taiwan. Energy Economics, 26, 201224.

Hondroyiannis, G., 2004. Estimating residential demand for electricity in Greece. Energy Economics, 26, 319-334.

Hosoe, N., Akiyama, S., 2009. Regional electric power demand elasticities of Japan's industrial and commercial sectors. Energy Policy, 37, 4313-4319.

Hsiao, C., Mountain, D.M., 1994. A framework for regional modeling and impact analysis: An analysis of the demand for electricity by large municipalities in Ontario, Canada. Journal of Regional Science, 34, 361-385.

Hsing, Y., 1994. Estimation of residential demand for electricity with the cross-sectionally correlated and time-wise autoregressive model. Resource and Energy Economics, 16, 255-263.

Hsing, Y., 1992. Interstate differences in price and income elasticities: The case of natural gas. Review of Regional Studies, 22, 251-259.

Hsing, Y., 1990. On the variable elasticity of the demand for gasoline. Energy Economics, 13, 132-127.

Hughes, J., Knittel, C.R., Sperling, D., 2008. Evidence of a shift in the short-run price elasticity of gasoline demand. Energy Journal, 29, 113-135.

Hunt, L.C., Judge, G., Ninomiya, Y., 2003. Underlying trends and seasonality in UK energy demand: A sectoral analysis. Energy Economics, 25, 93-118.

Hunt, L.C., Ninomiya, Y., 2003. Unravelling trends and seasonality: A structural time series analysis of transport oil demand in the UK and Japan. Energy Journal, 24, 63-96.

Hunt, L.C., Ryan, 2014. Economic modelling of energy services: Rectifying misspecified energy demand functions. Surrey Energy Economics Discussion paper Series, 147. Surrey Energy Economics Centre, University of Surrey.

Hunt, L.C., Witt, R., 1995. An analysis of UK energy demand using multivariate cointegration. Surrey Energy Economics Discussion paper Series, 86.

Ibrahim, I., Hurst, C., 1990. Estimating energy and oil demand functions. Energy Economics, 12, 93-102.

Inglesi, R., 2010. Aggregate electricity demand in South Africa: Conditional forecasts to 2030. Applied Energy, 87, 197-204.

Inglesi-Lotz, R., 2011. The evolution of price elasticity of electricity demand in South Africa: a Kalman filter application. Energy Policy, 39, 3690-3696.

Inglesi-Lotz, R., Blignaut, J.N., 2011. Estimating the price elasticity of demand for electricity by sector in South Africa. South African Journal of Economic and Management Sciences, 4, 449-465.

lootty, M., Pinto Jr., H., Ebeling, F., 2009. Automotive fuel consumption in Brazil: applying static and dynamic systems of demand equations. Energy Policy, 37, 5326-5333.

Ishiguro, M., Akiyama, T., 1995. Energy demand in five major Asian developing countries. World Bank Discussion Papers, 277.

Ito, K., 2012. Do consumers respond to marginal or average price? Evidence from nonlinear electricity pricing. NBER Working Paper Series, 18533.

Ito, K., 2010. How do consumers respond to nonlinear pricing? Evidence from household electricity demand. Working Paper, University of California, Berkeley.

Iwayemi, A., Adenikinju, A., Babatunde, M.A., 2010. Estimating petroleum products demand elasticities in Nigeria: A multivariate cointegration approach. Energy Economics, 32, 73-85. 
Jamil, F., Ahmad, E., 2011. Income and price elasticities of electricity demand: Aggregate and sector-wise analyses. Energy Policy, 39, 5519-5527.

Jeong, J., Kim, C.S., Lee, J., 2011. Household electricity and gas consumption for heating homes. Energy Policy, 39, 2679-2687.

Johansson, O., Schipper, L., 1997. Measuring the long-run fuel demand of cars. Journal of Transport Economics and Policy, 31, 277-292.

Johnsen, T.A., 2001. Demand, generation and price in the Norwegian market for electric power. Energy Economics, 23, 227-251.

Jones, C.T., 1996. A pooled dynamic analysis of inter-fuel substitution in industrial energy demand by the G-7 countries. Applied Economics, 28, 815-821.

Jones, C.T., 1994. Accounting for technical progress in aggregate energy demand. Energy Economics, $16,245-252$.

Jorgenson, J., Joutz, F., 2011. Modelling and simulating long-run residential electricity consumption in the U.S. Mountain region. $18^{\text {th }}$ Federal Forecasters Conference, Issues in Forecasting and the Environment.

Joutz, F., Trost, R., Shin, D., McDowell, B., 2009. Estimating regional short-run and long-run price elasticities of residential natural gas demand in the U.S. USAEE WP 09-021.

Kamerschen, D. R., Porter, D. V., 2004. The demand for residential, industrial and total electricity, 19731998. Energy Economics, 26, 87-100.

Karimu, A., Brännlund, R., 2013. Functional form and aggregate energy demand elasticities: A nonparametric panel approach for 17 OECD countries. Energy Economics, 36, 19-27.

Kayser, H., 2000. Gasoline demand and car choice: Estimating gasoline demand using household information. Energy Economics, 22, 331-348.

Khan, M.A., Qayyum, A., 2009. The demand for electricity in Pakistan. OPEC Energy Review, 33, 70-96.

Kim, H.G., 2007. An analysis of income distribution effects of a gasoline tax: Evidence from the U.S. micro-level data. Ph.D. thesis, University of Missouri-Columbia.

Kim, S.R., 2004. Environmental taxes and economic welfare: The welfare cost of gasoline taxation in the U.S. 1995-99. The ICFAI Journal of Environmental Economics, 2.

Kohler, M., 2014. Differential electricity pricing and energy efficiency in South Africa. Energy, 64, 524-532.

Kokkelenberg, E.C., Mount, T.D., 1993. Oil shocks and the demand for electricity. Energy Journal, 14, 113-139.

Koshal, R.K., Koshal, M., Luthra, K.L., Lindey, J.D., 1990. Production and high energy prices. A case of some Pan-Pacific countries. Energy Economics, 12, 197-203.

Koshal, R.K., Koshal, M., Yamada, Y., Miyazima, S., Yamamoto, K., 2007. Demand for gasoline in Japan. International Journal of Transport Economics, 34, 351-367.

Krichene, N., 2002. World crude oil and natural gas: A demand and supply model. Energy Economics, 24, $557-576$.

Labandeira, X., Labeaga, J.M., López-Otero, X., 2012. Estimation of elasticity price of electricity with incomplete information. Energy Economics, 34, 627-633.

Labandeira, X., Labeaga, J., Rodríguez, M., 2006. A residential energy demand system for Spain. Energy Journal, 27, 87-112.

Labandeira, X., López-Nicolás, A. 2002. La imposición de los carburantes de automoción en España: algunas observaciones técnicas y empíricas. Hacienda Pública Española. Revista de Economía Pública, 160, $177-210$.

Labeaga, J. M., Lopez, A., 1997. A study of petrol consumption using Spanish panel data. Applied Economics, 29, 795-802. 
Lampin, L.B.A., Nadaud, F., Grazi, F., Hourcade, J.C., 2013. Long-term fuel demand: Not only a matter of fuel price. Energy Policy, 62, 780-787.

Lee, C.C., Chiu, Y. B., 2011. Electricity demand elasticities and temperature: Evidence from panel smooth transition regression with instrumental variable approach. Energy Economics, 33, 896-902.

Lee, C., Lee, J., 2010. A panel data analysis of the demand for total energy and electricity in OECD countries. Energy Journal, 31, 1-24.

Lee, M., 2013. The effects of an increase in power rate on energy demand and output price in Korean manufacturing sectors. Energy Policy, 63, 1217-1223.

Leth-Petersen, s., Togeby, M., 2001. Demand for space heating in apartment blocks: Measuring effects of policy measures aiming at reducing energy consumption. Energy Economics, 23, 387-403.

Li, Z., Rose, J.M., Hensher, D.A., 2010. Forecasting automobile petrol demand in Australia: An evaluation of empirical models. Transportation Research Part A, 44, 16-38.

Liddle, B., 2012. The systematic, long-run relation among gasoline demand, gasoline price, income, and vehicle ownership in OECD countries: Evidence from panel cointegration and causality modeling. Transportation Research Part D: Transport and Environment, 17, 327-331.

Lijesen, M.G., 2007. The real-time price elasticity of electricity. Energy Economics, 29, 249-258.

Lim, K.M., Kim, M., Kim, C.S., Yoo, S.H., 2012. Short-run and long-run elasticities of diesel demand in Korea. Energies, 5, 5055-5064.

Lim, K.M., Lim, S.Y., Yoo, S.H., 2014. Short- and long-run elasticities of electricity demand in the Korean service sector. Energy Policy, 67, 517-521.

Lin, B.Q., 2003. Electricity demand in the People's Republic of China: investment requirement and environmental impact. ERD Working Paper Series, 37, Asian Development Bank.

Lin, C.Y. C., Prince, L., 2013. Gasoline price volatility and the elasticity of demand for gasoline. Energy Economics, 38, 111-117.

Lin, C.Y. C., Prince, L., 2009. The optimal gas tax for California. Energy Policy, 37, 5173-5183.

Lin, C.Y. C., Zeng, J., 2013. The elasticity of demand for gasoline in China. Energy Policy, 59, 189-197.

Liu, G., 2004. Estimating energy demand elasticities for OECD countries. A dynamic panel data approach. Discussion Papers, 373, Statistics Norway, Research Department.

Lundberg, L., 2009. An econometric analysis of the Swedish industrial electricity demand. Master thesis. Lulea University of Technology.

Maddala, G.S., Trost, R.P., Li, H., Joutz, F., 1997. Estimation of short-run and long-run elasticities of energy demand from panel data using shrinkage estimators. Journal of Business and Economic Statistics, $15,90-100$.

Maddock, R., Castaño, E., Vella, F., 1992. Estimating electricity demand: The cost of linearising the budget constraint. Review of Economics and Statistics, 74, 350-354.

Madlener, R., Alt, R., 1996. Residential energy demand analysis: An empirical application of the closure test principle. Empirical Economics, 21, 203-220.

Madowitz, M., Novan, K., 2013. Gasoline taxes and revenue volatility: An application to California. Energy Policy, 59, 663-673.

Mahmud, F., Chishti, S., 1990. The demand for energy in the large-scale manufacturing sector of Pakistan. Energy Economics, 12, 251-254.

Mahmud, S.F., 2000. The energy demand in the manufacturing sector of Pakistan: some further results. Energy Economics, 22, 641-648.

Mansur, E., Mendelsohn, R., Morrison, W., 2005. A discrete-continuous choice model of climate change impacts on energy. Yale SOM Working Paper, ES-43. 
Matsukawa, I., Fuji, Y., 1993. Price, environmental regulation, and fuel demand: Econometric estimates for Japanese manufacturing industries. Energy Journal, 14, 37-56.

McNown, R.F., Pourgerami, A., von Hirschhausen, C.R., 1991. Input substitution in manufacturing for three LDCs: translog estimates and policy implications. Applied Economics, 23, 209-218.

McRae, R., 1994. Gasoline demand in developing Asian countries. Energy Journal, 15, 143-155.

Medlock III, K.B., Soligo, R., 2001. Economic development and end-use energy demand. Energy Journal, 22, 77-105.

Mehrara, M., Ahmadi, S., 2011. The estimation of the automotive fuel demand in Iran: almost ideal demand system approach. Australian Journal of Business and Management Research, 1, 72-77.

Meier, H., Rehdanz, K., 2010. Determinants of residential space heating expenditures in Great Britain. Energy Economics, 32, 949-959.

Mitchell, T., 2006. A co-integration analysis of the price and income elasticity of energy demand. Research Department, Central Bank of Barbados.

Morana, C., 2000. Modelling evolving long-run relationships: an application to the Italian energy market. Scottish Journal of Political Economy, 47, 72-93.

Mountain, D.C., 1994. An overall assessment of the responsiveness of households to time-of-use electricity rates: the Ontario experiment. Energy Studies Review, 5, 190-203.

Munley, V.G., Taylor, L.W., Fromby, J.P., 1990. Electricity demand in multi-family, renter-occupied residences. Southern Economic Journal, 57, 178-194.

Nagata, Y., 2002. A forecast of energy demand in Japan considering asymmetric price elasticities. Energy Studies Review, 10, 17-26.

Nahata, B., Izyumov, A., Busygin, V., Mishura, A., 2007. Application of Ramsey model in transition economy: A Russian case study. Energy Economics, 29, 105-125.

Nakajima, T., 2010. The residential demand for electricity in Japan: An examination using empirical panel analyisis techniques. Journal of Asian Economics, 21, 412-420.

Nakajima, T., Hamori, S., 2010. Change in consumer sensitivity to electricity prices in response to retail deregulation: A panel empirical analysis of the residential demand for electricity in the United States. Energy Policy, 38, 2470-2476.

Nan, G.D., Murry, D.A., 1992. Energy demand with the flexible double-logarithmic functional form. Energy Journal, 13, 149-159.

Narayan, P. K., Smyth, R., Prasad, A., 2007. Electricity consumption in G7 countries: A panel cointegration analysis of residential demand elasticities. Energy Policy, 35, 4485-4494.

Narayan, P. K., Smyth, R., 2005. The residential demand for electricity in Australia: An application of the bounds testing approach to cointegration. Energy Policy, 33, 467-474.

Narwold, A., Yandell, D., 2013. Short-run driver response to a gasoline price spike: Evidence from San Diego, CA. Journal of Applied Business and Economics, 15, 23-32.

Nasir, M., Tariq, M.S., Arif, A., 2008. Residential demand for electricity in Pakistan. Pakistan Development Review, 47, 457-467.

Nesbakken, R., 2001. Energy consumption for space heating: A discrete-continuous approach. Scandinavian Journal of Economics, 103, 164-184.

Nesbakken, R., 1999. Price sensitivity of residential energy consumption in Norway. Energy Economics, 21, 493-515.

Neto, D., 2012. Testing and estimating time-varying elasticities of Swiss gasoline demand. Energy Economics, 34, 1755-1762. 
Newell, R.G., Pizer, W.A., 2008. Carbon mitigation costs for the commercial building sector: Discretecontinuous choice analysis of multi-fuel energy demand. Resource and Energy Economics, 30, 527-539.

Ngui, D., Mutua, J., Osiolo, H., Aligula, E., 2011. Household energy demand in Kenya: an application of the linear approximate almost ideal demand system (LA-AIDS). Energy Policy, 39, 7084-7094.

Nicol, C. J., 2003. Elasticities of demand for gasoline in Canada and the United States. Energy Economics, 25, 201-214.

Nwachukwu, M.U., Chike, H., 2011. Fuel subsidy in Nigeria: Fact or fallacy. Energy, 36, 2796-2801.

Okajima, S., Okajima, H., 2013. Estimation of Japanese price elasticities of residential electricity demand, 1990-2007. Energy Economics, 40, 433-440.

Oladosu, G., 2003. An almost ideal demand system model of household vehicle fuel expenditure allocation in the United States. Energy Journal, 24, 1-23.

Olivia, S., Gibson, J., 2008. Household energy demand and equity and efficiency aspects of subsidy reform in Indonesia. Energy Journal, 29, 21-40.

Orasch, W., Wirl, F, 1997. Technological efficiency and the demand for energy (road transport). Energy Policy, 25, 1129-1136.

Park, S.Y., Zhao, G., 2010. An estimation of U.S. gasoline demand: A smooth time-varying cointegration approach. Energy Economics, 32, 110-120.

Paul, A., Myers, E., Palmer, K., 2009. A partial adjustment model of U.S. electricity demand by region, season and sector. Discussion Paper, 08-50, Resources for the Future.

Payne, J.E., Loomis, D., Wilson, R., 2011. Residential natural gas demand in Illinois: Evidence from the ARDL bounds testing approach. Regional Analysis and Policy, 41, 138-147.

Phoumin, H., Kimura, S., 2014. Analysis on price elasticity of energy demand in East Asia: Empirical evidence and policy implications for ASEAN and East Asia. ERIA Discussion Paper 2014-05.

Pielow, A., Sioshansi, R., Roberts, M.C., 2012. Modeling short-run electricity demand with long-term growth rates and consumer price elasticity in commercial and industrial sectors. Energy, 46, 533-540.

Pock, M., 2010. Gasoline demand in Europe: New insights. Energy Economics, 32, 54-62.

Pokharel, S., 2007. An econometric analysis of energy consumption in Nepal. Energy Policy, 35, 350-361.

Polemis, M.L., 2007. Modeling industrial energy demand in Greece using cointegration techniques. Energy Policy, 35, 4039-4050.

Polemis, M.L., 2006. Empirical assessment of the determinants of road energy demand in Greece. Energy Economics, 28, 385-403.

Polemis, M.L., Dagoumas, A.S., 2013. The electricity consumption and economic growth nexus: Evidence from Greece. Energy Policy, 62, 798-808.

Poyer, D.A., Williams, M., 1993. Residential energy demand: additional empirical evidence by minority household type. Energy Economics, 15, 93-100.

Puller, S.L., Greening, L.A., 1999. Household adjustment to gasoline price change: An analysis using 9 years of US survey data. Energy Economics, 21, 37-52.

Radchenko, S., Tsurumi, H., 2006. Limited information Bayesian analysis of a simultaneous equation with an autocorrelated error term and its application to the U.S. gasoline market. Journal of Econometrics, 133, 31-49.

Ramanathan, R., 1999. Short- and long-run elasticities of gasoline demand in India: An empirical analysis using cointegration techniques. Energy Economics, 21, 321-330.

Ramcharran, H., 1990. Electricity consumption and economic growth in Jamaica. Energy Economics, 12, 65-70. 
Rao, B.B., Rao, G., 2009. Cointegration and the demand for gasoline. Energy Policy, 37, 3978-3983.

Rapanos, V., Polemis, M., 2006. The structure of residential energy demand in Greece. Energy Policy, 34, 3137-3143.

Rapson, D., 2014. Durable goods and long-run electricity demand: evidence from air conditioner purchase behavior. Journal of Environmental Economics and Management, 68, 141-160.

Rehdanz, K., 2007. Determinants of residential space heating expenditures in Germany. Energy Economics, 29, 167-182.

Reiss, P., White, M., 2005. Household electricity demand revisited. Review of Economic Studies, 72, 853883.

Renou-Maissant, P., 1999. Inter-fuel competition in the industrial sector of seven OECD countries. Energy Policy, 27, 99-110.

Reyes, O., Escalante, R., Matas, A., 2010. La demanda de gasolinas en México: Efectos y alternativas ante el cambio climático. Economía: Teoría y Práctica, 32, 83-111.

Romero-Jordán, D., del Río, P., Jorge-García, M., Burguillo, M., 2010. Price and income elasticities of demand for passenger transport fuels in Spain. Implications for public policies. Energy Policy, 38, 38983909.

Romero-Jordán, D., del Río, P., Peñasco, C., 2014. Household electricity demand in Spanish regions. Public policy implications. Document de treball, 2014/24, Institut d'Economia de Barcelona.

Roppa, B.F., 2005. Evolução do consumo de gasolina no Brasil e suas elasticidades: 1973 a 2003. Monografia de Bacharelado. Instituto de Economia, Universidade Federal do Rio de Janeiro.

Rothman, D.S., Hong, J.H., Mount, T.D., 1994. Estimating consumer energy demand using international data: Theoretical and policy implications. Energy Journal, 15, 67-88.

Roy, J., Sathaye, J., Sanstad, A., Mongia, P., Schumacher, K., 1999. Productivity trends in India's energy intensive industries. Energy Journal, 20, 33-61.

Ryan, D.L., Wang, Y., Plourde, A., 1996. Asymmetric price responses of residential energy demand in Ontario. Canadian Journal of Economics, 29, S317-S323.

Sa'ad, 2011. Underlying energy demand trends in South Korean and Indonesian aggregate whole economy and residential sectors. Energy Policy, 39, 40-46.

Sa'ad, 2010. Improved technical efficiency and exogenous factors in transportation demand for energy: An application of structural time series analysis to South Korean data. Energy, 35, 2745-2751.

Sa'ad, S., 2009a. An empirical analysis of petroleum demand for Indonesia: An application of the cointegration approach. Energy Policy, 37, 4391-4396.

Sa'ad, S., 2009b. Electricity demand for South Korean residential sector. Energy Policy, 37, 5469-5474.

Sa'ad, S., 2009c. Transportation demand for petroleum products in Indonesia: A time series analysis. OPEC Review, 33, 140-154

Sa'ad, S., Shahbaz, M., 2012. Price and income elasticities of demand for oil products in African member countries of OPEC: A cointegration analysis. MPRA Paper, 37390.

Sabir, M., Ahmad, N., Bashir, M.K., 2013. Demand function of electricity in industrial sector of Pakistan. World Applied Sciences Journal, 21, 641-645.

Salehi-Isfahani, D., 1996. Government subsidies and demand for petroleum products in Iran. In Pfeifer, K. (ed.), Research in Middle East Economics Volume 1. JAI Press, Greenwich.

Salgado, H., Bernal, L.E., 2007. Translog cost functions: An application for Mexican manufacturing. Working Paper, 2007-08, Banco de México.

Samimi, R., 1995. Road transport energy demand in Australia. Energy Economics, 17, 329-339. 
Santos, G.F., 2013. Fuel demand in Brazil in a dynamic panel data approach. Energy Economics, 36, 229240.

Saunoris, J.W., Sheridan, B.J., 2013. The dynamics of sectoral electricity demand for a panel of US states: New evidence on the consumption-growth nexus. Energy Policy, 61, 327-336.

Schmalensee, R., Stocker, T.M., 1999. Household gasoline demand in the United States. Econometrica, 67, 645-662.

Scott, K.R., 2013. Demand and price uncertainty: Rational habits in international gasoline demand. CUDARE Working Paper, 1131, UC Berkeley.

Scott, K.R., 2012. Rational habits in gasoline demand. Energy Economics, 34, 1713-1723.

Seale Jr., J., Walker, W.E., Kim, I.M., 1991. The demand for energy: Cross-country evidence using the Florida model. Energy Economics, 13, 33-40.

Semboja, H.H., 1994. A dynamic model of industrial energy demand in Kenya. Energy Journal, 15, $203-$ 224.

Sene, S.O., 2012. Estimating the demand for gasoline in developing countries: Senegal. Energy Economics, 34, 189-194.

Sentenac-Chemin, E., 2012. Is the price effect on fuel consumption symmetric? Some evidence from an empirical study. Energy Policy, 41, 59-65.

Serletis, A., Timilsina, G.R., Vasetsky, O., 2010. Inter-fuel substitution in the United States. Energy Economics, 32, 737-745.

Shahmoradi, A., Honarvar, A., 2008. Gasoline subsidy and consumer surplus in the Islamic Republic of Iran. OPEC Review, 32, 232-245.

Sharma, D.P., Nair, P.S.C., Balasubramanian, R., 2002. Demand for commercial energy in the state of Kerala, India: An econometric analysis with medium-range projections. Energy Policy, 30, 781-791.

Sheinbaum, C., Martínez, M., Rodríguez, L., 1996. Trends and prospects in Mexican residential energy use. Energy, 21, 493-504.

Shi, G., Zheng, X., Song, F., 2012. Estimating elasticity for residential electricity demand in China. The Scientific World Journal, 2012, 1-6.

Silk, J.I., Joutz, F.L., 1997. Short and long-run elasticities in US residential electricity demand: A cointegration approach. Energy Economics, 19, 493-513.

Silva, G.F., Tiryaki, G. F., Pontes, L. A. M., 2009. The impact of a growing ethanol market on the demand elasticity for gasoline in Brazil. USAEE 34th International Conference on Energy Economics.

Sipes, K.N., Mendelsohn, R., 2001. The effectiveness of gasoline taxation to manage air pollution. Ecological Economics, 36, 299-309.

Small, K.A., van Dender, K., 2007. Fuel efficiency and motor vehicle travel: The declining rebound effect. Energy Journal, 28, 25-51.

Sterner, T., Dahl, C., Franzen, M., 1992. Gasoline tax policy, carbon emissions and the global environment. Journal of Transport Economics and Policy, 26, 109-119.

Storchmann, K., 2005. Long-run gasoline demand for passenger cars: The role of income distribution. Energy Economics, 27, 25-58.

Su, Q., 2008. The effect of population density, road network density, and congestion on household gasoline consumption in U.S. urban areas. Energy Economics, 33, 445-452.

Sudarshan, A., 2013. Deconstructing the Rosenfeld curve: Making sense of California's low electricity intensity. Energy Economics, 39, 197-207.

Sun, C., Lin, B., 2013. Reforming residential electricity tariff in China: Block tariffs pricing approach. Energy Policy, 60, 741-752. 
Taheri, A.A., Stevenson, R., 2002. Energy price, environmental policy, and technological bias. Energy Journal, 23, 85-107.

Taylor, T.N., Schwarz, P.M., 1990. The long-run effects of a time-of-use demand charge. RAND Journal of Economics, 21, 431-445.

Taylor, T.N., Schwarz, P.M., Cochell, J.E., 2005. 24/7 hourly response to electricity real-time pricing with up to eight summers of experience. Journal of Regulatory Economics, 27, 235-262.

Tiwari, P., 2000. Architectural, demographic, and economic causes of electricity consumption in Bombay. Journal of Policy Modeling, 22, 81-99.

Urga, 1999. An application of dynamic specifications of factor demand equations to inter-fuel substitution in U.S. industrial energy demand. Energy Modelling, 16, 503-513.

Urga, G., Walters, C., 2003. Dynamic translog and linear logit models: A factor demand analysis of interfuel substitution in US industrial energy demand. Energy Economics, 25, 1-21.

Vaage, K., 2000. Heating technology and energy use: A discrete/continuous choice approach to Norwegian household energy demand. Energy Economics, 22, 649-666.

van Benthem, A., Romani, M., 2009. Fuelling growth: What drives energy demand in developing countries? Energy Journal, 30, 91-114.

Vásquez, A., 2005. La demanda agregada de combustibles líquidos en el Perú. Documento de Trabajo, 12, Oficina de Estudos Económicos, OSINERG.

Vásquez, F., Dale, L., Hanemann, M., Moezzi, M., 2011. The impact of price on residential demand for electricity and natural gas. Climatic Change, 109, S171-S189.

Virley, S., 1993. The effect of fuel price increases on road transport $\mathrm{CO}_{2}$ emissions. Transport Policy, 1 , 43-48.

Wadud, Z., Dey, H.S., Kabir, M.A., Khan, S.I., 2011. Modeling and forecasting natural gas demand in Bangladesh. Energy Policy, 39, 7372-7380.

Wadud, Z., Graham, D.J., Noland, R.B., 2010a. Gasoline demand with heterogeneity in household responses. Energy Journal, 31, 47-74.

Wadud, Z., Noland, R.B., Graham, D.J., 2010b. A semiparametric model of household gasoline demand. Energy Economics, 32, 93-101.

Wadud, Z., Graham, D.J., Noland, R.B., 2009. A cointegration analysis of gasoline demand in the United States. Applied Economics, 41, 3327-3336.

Walker, I.O., Wirl, F., 1993. Irreversible price-induced efficiency improvements: Theory and empirical application to road transportation. Energy Journal, 14, 183-205.

Wang, T., Lin, B., 2014. China's natural gas consumption and subsidies from a sector perspective. Energy Policy, 65, 541-551.

West, S., 2004. Distributional effects of alternative vehicle pollution control policies. Journal of Public Economics, 88, 735-757.

West, S., Williams III, R.C., 2004. Estimates from a consumer demand system: Implications for the incidence of environmental taxes. Journal of Environmental Economics and Management, 47, 535-558.

Wirl, F., 1991. Energy demand and consumer price expectations. An empirical investigation of the consequences form the recent oil price collapse. Resources and Energy, 13, 241-262.

Wohlgemuth, N., 1997. World transport energy demand modelling. Methodology and elasticities. Energy Policy, 25, 1109-1119.

Woodland, A.D., 1993. A micro-econometric analysis of the industrial demand for energy in NSW. Energy Journal, 14, 57-89. 
Yanagisawa, A., 2011. Estimation of energy demand in Japan considering socio-economic structure change. The Institute of Energy Economics, Japan.

Yatchew, A., No, J.A., 2001. Household gasoline demand in Canada. Econometrica, 69, 1697-1709.

Yi, F., 2000. Dynamic energy-demand models: a comparison. Energy Economics, 22, 285-297.

Yokoyama, A., Ueta, K., Fujikawa, K., 2000. Green tax reform: converting implicit carbon taxes to a pure carbon tax. Environmental Economics and Policy Studies, 3, 1-20.

Yoo, S.-H., Lee, J.S., Kwak, S.J., 2007. Estimation of residential electricity demand function in Seoul by correction for sample selection bias. Energy Policy, 35, 5702-5707.

Yoo, S.-H., Lim, H.-J., Kwak, S.J., 2009. Estimating the residential demand function for natural gas in Seoul with correction for sample selection bias. Applied Energy, 86, 460-465.

Yu, Y., Zheng, X., Han, Y., 2014. On the demand for natural gas in urban China. Energy Policy, 70, 57-63.

Yuan, C., Liu, S., Wu, J., 2010. The relationship among energy prices and energy consumption in China. Energy Policy, 38, 197-207.

Zachariadis, T., Pashourtidou, N., 2007. An empirical analysis of electricity consumption in Cyprus. Energy Economics, 29, 183-198.

Zarnikau, J., 1990. Customer responsiveness to real-time pricing of electricity. Energy Journal, 11, 99-116.

Zarnikau, J., Landreth, G., Hallett, I., Kumbhakar, S.C., 2007. Industrial customer response to wholesale prices in the restructured Texas electricity market. Energy, 32, 1715-1723.

Zhou, S., Teng, F., 2013. Estimation of urban residential electricity demand in China using household survey data. Energy Policy, 61, 394-402.

Ziramba, E., 2008. The demand for residential electricity in South Africa. Energy Policy, 36, 3460-3466.

Ziramba, E., Kavezeri, K., 2012. Long-run price and income elasticities of Namibian aggregate electricity demand: Results from the bounds testing approach. Journal of Emerging Trends in Economics and Management Sciences, 3, 203-209. 